\title{
Involvement of Insulin-Like Peptide in Long-Term Synaptic Plasticity and Long-Term Memory of the Pond Snail Lymnaea stagnalis
}

\author{
Jun Murakami, ${ }^{1}$ Ryuichi Okada, ${ }^{1}$ Hisayo Sadamoto, ${ }^{1}$ Suguru Kobayashi, ${ }^{1}$ Koichi Mita, ${ }^{1}$ Yuki Sakamoto, ${ }^{1}$ \\ Miki Yamagishi, ${ }^{1}$ Dai Hatakeyama, ${ }^{1}$ Emi Otsuka, ${ }^{1}$ Akiko Okuta, ${ }^{2}$ Hiroshi Sunada, ${ }^{3}$ Satoshi Takigami, ${ }^{3}$ \\ Manabu Sakakibara, ${ }^{3}$ Yutaka Fujito, ${ }^{4}$ Masahiko Awaji, ${ }^{5}$ Shunsuke Moriyama, ${ }^{6}$ Ken Lukowiak, ${ }^{7}$ and Etsuro Ito ${ }^{1}$ \\ ${ }^{1}$ Laboratory of Functional Biology, Kagawa School of Pharmaceutical Sciences, Tokushima Bunri University, Sanuki 769-2193, Japan, ${ }^{2}$ Department of Biophysics, \\ Graduate School of Science, Kyoto University, Kyoto 606-8502, Japan, ${ }^{3}$ Department of Biological Science and Technology, School of High-Technology for Human \\ Welfare, Tokai University, Numazu 410-0321, Japan, ${ }^{4}$ Department of Systems Neuroscience, School of Medicine, Sapporo Medical University, Sapporo 060-8556, \\ Japan, ${ }^{5}$ National Research Institute of Aquaculture, Fisheries Research Agency, Minamiise 516-0193, Japan, ${ }^{6}$ Laboratory of Aquatic Functional Biology, School of \\ Marine Biosciences, Kitasato University, Sagamihara 252-0373, Japan, and 7Hotchkiss Brain Institute, University of Calgary, Calgary, Alberta, Canada, T2N 4N1
}

The pond snail Lymnaea stagnalis is capable of learning taste aversion and consolidating this learning into long-term memory (LTM) that is called conditioned taste aversion (CTA). Previous studies showed that some molluscan insulin-related peptides (MIPs) were upregulated in snails exhibiting CTA. We thus hypothesized that MIPs play an important role in neurons underlying the CTA-LTM consolidation process. To examine this hypothesis, we first observed the distribution of MIP II, a major peptide of MIPs, and MIP receptor and determined the amounts of their mRNAs in the CNS. MIP II was only observed in the light green cells in the cerebral ganglia, but the MIP receptor was distributed throughout the entire CNS, including the buccal ganglia. Next, when we applied exogenous mammalian insulin, secretions from MIP-containing cells or partially purified MIPs, to the isolated CNS, we observed a long-term change in synaptic efficacy (i.e., enhancement) of the synaptic connection between the cerebral giant cell (a key interneuron for CTA) and the B1 motor neuron (a buccal motor neuron). This synaptic enhancement was blocked by application of an insulin receptor antibody to the isolated CNS. Finally, injection of the insulin receptor antibody into the snail before CTA training, while not blocking the acquisition of taste aversion learning, blocked the memory consolidation process; thus, LTM was not observed. These data suggest that MIPs trigger changes in synaptic connectivity that may be correlated with the consolidation of taste aversion learning into CTA-LTM in the Lymnaea CNS.

\section{Introduction}

Formation of long-term memory (LTM) after associative learning is dependent on both protein synthesis and altered gene activity in neurons that play a critical role in memory formation (Inda et al., 2005; Lee et al., 2008; Rosenegger et al., 2010). The pond snail Lymnaea stagnalis is a good model in which to elucidate the causal mechanisms that underlie LTM formation (Ito et al., 1999, 2012a; Sakakibara, 2006; Lukowiak et al., 2008; Nikitin et al., 2008; Kemenes and Benjamin, 2009). In conditioned taste aversion (CTA), a form of associative learning, an appetitive stimulus (sucrose) is used as the conditioned stimulus (CS), and

\footnotetext{
Received Feb. 6, 2012; revised 0ct. 27, 2012; accepted Nov. 14, 2012.

Author contributions: J.M., A.O., M.S., Y.F., M.A., K.L., and E.I. designed research; J.M., R.O., H.Sa., S.K., K.M., Y.S., M.Y., D.H., E.O., A.O., H.Su., S.T., M.S., M.A., S.M., K.L., and E.I. performed research; J.M., R.O., H.Sa., S.K., K.M., Y.S., M.Y., D.H., E.O., A.O., H.Su., S.T., M.S., M.A., S.M., K.L., and E.I. analyzed data; J.M., R.O., A.O., M.S., Y.F., M.A., S.M., K.L., and E.I. wrote the paper.

This work was supported by a KAKENHI grant from Japan Society for the Promotion of Science [Grants 21770081 (H.Sa.) and 21657022 (E.I.)] and a grant from Canadian Institutes of Health Research (No. MOP 64339 to K.L.).

Correspondence should be addressed to Etsuro Ito, Laboratory of Functional Biology, Kagawa School of Pharmaceutical Sciences, Tokushima Bunri University, 1314-1 Shido, Sanuki 769-2193, Japan. E-mail: eito@kph.bunriu.ac.jp.

DOI:10.1523/JNEUROSCI.0679-12.2013

Copyright $\odot 2013$ the authors $\quad 0270-6474 / 13 / 330371-13 \$ 15.00 / 0$
}

an aversive stimulus $(\mathrm{KCl})$ is used as the unconditioned stimulus (US). The CS increases the feeding response in snails, whereas the US inhibits feeding. In CTA training, the CS is paired with the US. After repeated paired presentations, the CS no longer elicits the feeding response, and this aversive conditioning persists as LTM (Kojima et al., 1996).

We identified candidate genes necessary for the establishment of CTA-LTM in Lymnaea and found that some genes were upregulated while others were downregulated (Azami et al., 2006). Some of the upregulated genes after LTM consolidation were the molluscan insulin-related peptide (MIP I, II, and others) genes. However, it is unclear whether MIPs are necessary for memory consolidation, and if they are, what is their role in the consolidation process.

Peptide purification of MIP I-III and V and the additional finding of a MIP VII transcript indicate that five types of MIPs function in Lymnaea (Li et al., 1992a, b, c; Smit et al., 1991, 1993, 1996). Protein structures for the insulin superfamily peptides in invertebrates and vertebrates are also well conserved in these MIPs, and their expression is observed in the growth-controlling neuroendocrine light green cells (LGCs) and canopy cells of the cerebral ganglia (Meester et al., 1992; Smit et al., 1992, 1998). The 
cDNA structure of a putative tyrosine kinase receptor for MIPs has also been clarified (Roovers et al., 1995). Many of the typical insulin receptor features, including a cysteine-rich domain, a single transmembrane domain, and a tyrosine kinase domain, are also conserved in the predicted 1607 amino acid protein in Lymnaea. Extensive screening of cDNA and genomic libraries together with Southern blot analyses have revealed the presence of a single putative MIP receptor gene and suggested that different MIPs bind to the same receptor (Smit et al., 1996).

In the present study, we sought to clarify possible roles of MIPs in the CTA memory consolidation process. We first delineated the distribution of MIP II and MIP receptor mRNAs in the CNS in Lymnaea. We then investigated the effect of the exogenous application of partially purified MIPs on plasticity of synapses that play a role in CTA. Finally, we inhibited behavioral CTA-LTM by injection of the insulin receptor antibody into the snail before training. Our data are consistent with the hypothesis that MIPs play a key role in memory consolidation.

\section{Materials and Methods}

Snails. Specimens of $L$. stagnalis (L.) with a $15-25 \mathrm{~mm}$ shell [young adults (Sadamoto et al., 2000)] were obtained from our snail-rearing facility (original stocks from Vrije Universiteit Amsterdam). All snails were maintained in dechlorinated tap water (i.e., pond water) under a $12 \mathrm{~h}$ light/dark cycle at $20^{\circ} \mathrm{C}$ and fed ad libitum on a kind of turnip leaf, Brassica rapa var. peruviridis [Komatsuna (in Japanese)], and a spiral shell food (Nisso) every other day. Lymnaea exhibit good growth and reproduction under these feeding conditions. Snails were anesthetized with 25\% Listerine before dissection (Kojima et al., 1997). To obtain good marks for behavioral training, snails were not fed for $1 \mathrm{~d}$ in the behavioral experiments (Sugai et al., 2007). This protocol motivates snails for taste aversion training.

In situ hybridization. As one example, we performed in situ hybridization for MIP II among MIPs. We prepared the digoxigenin (DIG)labeled cRNA probes for MIP II antisense, MIP II sense, MIP receptor antisense, and MIP receptor sense. The sequences of MIP II and MIP receptor mRNAs were obtained from the NCBI Nucleotide database (MIP II, X59302; MIP receptor, X84994). The PCR products of MIP II (466 bp) and MIP receptor (445 or 528 bp) were subcloned with TOPO TA Cloning kit dual promoter (Invitrogen). After linearization with EcoRV or BamHI, the cRNA probes were synthesized by run-off transcription from T7 promoter for the MIP II sense and the MIP receptor antisense or from Sp6 promoter for the MIP II antisense and the MIP receptor sense with DIG RNA labeling mixture (Roche Diagnostics).

The CNSs were dissected from snails in ice-cold Lymnaea saline. The Lymnaea saline consisted of (in mM) $50 \mathrm{NaCl}, 1.6 \mathrm{KCl}, 2.0 \mathrm{MgCl}_{2}, 3.5$ $\mathrm{CaCl}_{2}$, and 10 HEPES, pH 7.9 (Straub et al., 2002). The dissected CNSs in OCT compound (Sakura Finetek, Tokyo, Japan) were frozen in liquid nitrogen. Then the specimens were cut on a cryostat. The horizontal frozen sections (10-14 $\mu \mathrm{m}$ thick) were thaw-mounted on glass slides precoated with Vecta-Bond (Vector Laboratories). The method of in situ hybridization was modified from Matsuo and Ito (2009). The sections were fixed in $10 \%$ formaldehyde neutral buffer, $\mathrm{pH} 7$, rinsed with PBS, and treated with $0.3 \%$ Triton X-100 and $0.2 \mathrm{M} \mathrm{HCl}$. Then the sections were treated with $2 \mu \mathrm{g} / \mathrm{ml}$ proteinase $\mathrm{K}$, fixed in $10 \%$ formaldehyde neutral buffer, $\mathrm{pH} 7$, and treated with $2 \mathrm{mg} / \mathrm{ml}$ glycine in PBS. After prehybridization in $5 \times$ SSC containing $50 \%$ formamide, the hybridization was performed at $52^{\circ} \mathrm{C}$ overnight in a hybridization buffer containing $50 \%$ formamide, $5 \times$ SSC, $100 \mu \mathrm{g} / \mathrm{ml}$ yeast tRNA, $0.1 \%$ Tween 20,50 $\mu \mathrm{g} / \mathrm{ml}$ heparine, and DIG-labeled cRNA probes. Subsequently, the slides were rinsed in $50 \%$ formamide in $4 \times \mathrm{SSC}$ at $52^{\circ} \mathrm{C}$, treated with RNase A $(0.02 \mathrm{mg} / \mathrm{ml})$ in buffer $(0.5 \mathrm{M} \mathrm{NaCl}, 10 \mathrm{~mm}$ Tris- $\mathrm{HCl}, \mathrm{pH} 7.5)$ for $30 \mathrm{~min}$ at $37^{\circ} \mathrm{C}$, and washed sequentially with $50 \%$ formamide in $1 \times$ SSC for $1 \mathrm{~h}$ at $52^{\circ} \mathrm{C}$. The slides were rinsed three times in buffer $(0.1 \mathrm{M}$ maleic acid, $\mathrm{pH} 7.5$, and $0.15 \mathrm{M} \mathrm{NaCl}$ ) at room temperature for a total of $10 \mathrm{~min}$ and rinsed in buffer [ $1 \%$ blocking reagent (Roche Diagnostics), $0.1 \mathrm{M}$ maleic acid, $\mathrm{pH} 7.5$, and $0.15 \mathrm{M} \mathrm{NaCl}$ ] for $30 \mathrm{~min}$. Hybridization signals were visualized using a nucleic acid detection kit (Roche Diagnostics) with alkaline phosphatase-conjugated anti-DIG antibody and nitroblue tetrazolium, according to the manufacturer's instructions.

Real-time PCR. The real-time PCR primers of MIP II (forward, 5' gggccaatcatcttgcagttt- $3^{\prime}$; reverse, $5^{\prime}$-ggaagccagccaaattcga- $3^{\prime}$ ) and MIP receptor (forward, 5' -agacagactactatagaaaaggaggtaaagga-3'; reverse, 5' acaactccatatgaccaaacatctga- $\left.3^{\prime}\right)$ were designed using Primer Express Software version 3.0 (Applied Biosystems).

The CNSs were dissected out from anesthetized Lymnaea, separated into three parts (buccal ganglia, cerebral ganglia, and other ganglia), and immediately frozen in liquid nitrogen. Total RNA of each part of the CNS was extracted using the RNAqueous-Micro kit (Applied Biosystems/Ambion). Twenty microliters of cDNA samples were obtained by reverse transcription of $50 \mathrm{ng}$ of total RNA that was taken from each part of the CNS. Real-time PCR was performed on the 7900HT Fast real-time PCR system (Applied Biosystems). We applied the absolute quantification method with the DyNAmo SYBR Green qPCR kit with ROX passive reference dye (Finnzymes). We also prepared standard samples [each solution containing $0.5 \times 10^{2}-0.5 \times 10^{6}$ copies of plasmid DNA (MIP II or MIP receptor)]. Each $10 \mu \mathrm{l}$ reaction contained $5 \mu \mathrm{l}$ of Master Mix (Finnzymes), $0.5 \mu \mathrm{M}$ forward primer, $0.5 \mu \mathrm{M}$ reverse primer, $0.2 \mu \mathrm{l}$ of $50 \times$ ROX passive reference dye, and $1 \mu \mathrm{l}$ of sample (cDNA sample or plasmid DNA standard sample). The PCR conditions were as follows: 1 cycle at $95^{\circ} \mathrm{C}$ for $10 \mathrm{~min}$, followed by 40 cycles at $95^{\circ} \mathrm{C}$ for $15 \mathrm{~s}$ and $58^{\circ} \mathrm{C}$ for $1 \mathrm{~min}$. After amplification, dissociation curves were obtained to ensure the specificity of PCR.

Secretions from the light green cells. The isolated CNS with the median lip nerves that include the axons of the LGCs (Li et al., 1992c) were pinned down in the chamber containing $5 \mathrm{ml}$ of Lymnaea saline that included a protease inhibitor, $5 \mu \mathrm{M}$ Pefabloc SC (4-(2-aminoethyl) benzenesulfonyl fluoride hydrochloride) (Roche Diagnostics). The median lip nerve was electrically stimulated with the hook electrodes every $5 \mathrm{~s}$ for $4 \mathrm{~h}$ at room temperature. One set of electrical stimulation consisted of 10 pulses with the amplitude of $1 \mathrm{~V}$, a duration of $50 \mathrm{~ms}$, and an interpulse interval of $100 \mathrm{~ms}$. This solution was filtered to retain MIPs, whose molecular mass is $6.9 \mathrm{kDa}$. Therefore, two ultrafiltration membranes, 3000 and 10,000 normal molecular weight limit (Ultra-0.5 ml and YM-10; Millipore), were used to collect proteins weighing between 3 and $10 \mathrm{kDa}$. The $50 \mu$ l of condensed solution, which was finally adjusted to contain the secretions from two CNSs, was used for the following electrophysiological studies. This solution was now called the "CNS factor solution" and was expected to contain MIPs. Furthermore, in some of our experiments, we immersed the CNSs with the median lip nerves in a small amount of Lymnaea saline at $4^{\circ} \mathrm{C}$ for $>20 \mathrm{~h}$ and obtained the CNS factor solution. The above two methods seemed to offer the same results in the electrophysiological experiments.

On the other hand, the CNSs without the cerebral ganglia (i.e., the CNSs without the LGCs or median lip nerves) were immersed in a small amount of Lymnaea saline at $4^{\circ} \mathrm{C}$ for $>20 \mathrm{~h}$. This solution was used as the control solution. As well as the CNS factor solution, the $50 \mu$ l solution, which was adjusted to contain the secretions from two CNSs, was used for the electrophysiological studies.

SDS-PAGE. SDS-PAGE was performed using the NuPAGE electrophoresis system (Invitrogen). Reduced samples that contained the CNS factor solution or the control solution were electrophoresized on $\mathrm{Nu}$ PAGE $10 \%$ gels with MES-SDS running buffer. Proteins in gels were stained with Oriole gel stain (Bio-Rad) at room temperature for $90 \mathrm{~min}$. Stained gels were photographed with a LAS3000 digital imaging analyzer (GE Healthcare). We should note that protein amounts on the gels could not be normalized for both the CNS factor solution sample and the control solution sample by measurement of an absorbance of $280 \mathrm{~nm}$. This issue was because the secretions from the CNS contained not only proteins but also miscellaneous things. Therefore, we adjusted the application amounts to the case that the condensed bands for the control solution samples were clearly visible on the gels.

To further confirm whether the cerebral ganglia possess the same small peptide as that secreted from the median lip nerves as mentioned above, we performed another SDS-PAGE using the CNS homogenate by tricine SDS-PAGE. The CNSs were dissected out from six snails and homoge- 
nized in $20 \mu \mathrm{l}$ of $0.1 \mathrm{M}$ acetic acid on ice. After centrifugation at 15,000 $\mathrm{rpm}$ at $4^{\circ} \mathrm{C}$ for $10 \mathrm{~min}$, the lysate was applied for tricine SDS-PAGE. As the control sample, the CNS lysate without the cerebral ganglia was prepared in the same way. The CNS lysate containing $18 \mu \mathrm{g}$ of total protein was subjected to tricine SDS-PAGE. The reduced samples containing the CNS lysate were electrophoresized on $16 \%$ polyacrylamide gel with the Tris-tricine buffer system. Proteins in gels were stained with Oriole gel stain (Bio-Rad) at room temperature for $90 \mathrm{~min}$. The stained gels were photographed with a LAS3000 digital imaging analyzer (GE Healthcare). Human insulin was purchased from MP Bio Japan.

Purification of MIPs. Extraction and purification of MIPs were conducted, in principle, following the procedures described by $\mathrm{Li}$ et al. (1992a). Forty-seven median lip nerves, stored at $-80^{\circ} \mathrm{C}$, were sonicated in $1 \mathrm{ml}$ of $1 \mathrm{M}$ acetic acid over ice and centrifuged for $15 \mathrm{~min}$ at 21,500 $\times$ $g$ at $4^{\circ} \mathrm{C}$. The supernatant was collected, and the precipitate was extracted again with $0.5 \mathrm{ml}$ of $1 \mathrm{M}$ acetic acid and centrifuged. The supernatants were combined and applied to a C18 solid-phase extraction column (Sep-Pak Vac 6cc; Waters). The bound materials were eluted with a mixture of $60 \%$ acetonitrile $(\mathrm{AcN}) / 7 \mathrm{~mm}$ trifluoroacetic acid (TFA) and subjected to high-performance gel permeation chromatography (HPGPC). The materials were injected into a column (TSKgel G2000SW, $7.5 \times 300 \mathrm{~mm}$; TOSOH) equilibrated with $30 \%$ AcN $7 \mathrm{~mm}$ TFA and eluted at a flow rate of $1 \mathrm{ml} / \mathrm{min}$. Fractions were collected every $1 \mathrm{~min}$. The fractions with the same elution position of bovine insulin were collected, freeze dried, and redissolved in $120 \mu \mathrm{l}$ of $30 \%$ AcN 7 mM TFA. This sample was subjected to reverse-phase high-performance chromatography (rpHPLC) using a C18 column (TSKgel ODS-120T, $4.6 \times 250$ $\mathrm{mm}$; TOSOH) equilibrated with $7 \mathrm{~mm}$ TFA at a flow rate of $1 \mathrm{ml} / \mathrm{min}$. The concentration of AcN in the $7.0 \mathrm{~mm}$ TFA was raised to $21 \%$ in $5 \mathrm{~min}$, to $39 \%$ in an additional $35 \mathrm{~min}$, to $45 \%$ in $5 \mathrm{~min}$, followed by a raise to $60 \%$ in the final $5 \mathrm{~min}$. One-minute fractions were collected, and a fraction regarded to contain partially purified MIPs was concentrated and used for electrophysiological experiments. The amount of peptides in the concentrated fraction was measured with the Quant-iT Protein Assay kit (Invitrogen). The same purification procedures were repeated again starting with 141 median lip nerves, and the rpHPLC fractions with the same elution pattern were obtained. The fraction regarded to contain partially purified MIPs was subjected to mass spectrometric analyses.

Mass spectrometry. The rpHPLC fractions were analyzed using an autoflex III matrix-assisted laser desorption/ionization-time of flight/time of flight mass spectrometry (MALDI-TOF/TOF MS; Bruker Daltonik) according to the method of Ohnishi et al. (2009). To confirm a presence of disulfide bonds, peptides were pretreated according to the method of Fukuyama et al. (2006).

Electrophysiology. We examined the properties of the chemical synapses between the cerebral giant cell (CGC) and its ipsilateral B1 motor neuron in the isolated Lymnaea CNS. The paired CGCs play a key role in the nervous control of the feeding system in Lymnaea (McCrohan and Benjamin, 1980; Kyriakides and McCrohan, 1989; Kojima et al., 1997, 2001; Nakamura et al., 1999a; Elliott and Vehovszky, 2000; Straub et al., 2007; Yeoman et al., 2008; Ito et al., 2012a), and the B1 motor neuron receives a monosynaptic excitatory input from the CGC (McCrohan and Benjamin, 1980; Kawai et al., 2011), is activated during the radulaprotraction phase in the feeding cycle (Rose and Benjamin, 1979), and innervates the salivary gland (Benjamin et al., 1979). The CGC also plays a major role in the mediation of LTM for both food aversive and food appetitive learning (Kojima et al., 1997; Benjamin et al., 2000). Kojima et al. (1997) showed that activity in the CGC caused a large and long-lasting polysynaptic inhibitory effect on the N1M cell, which is one of the feeding central pattern generator neurons, in snails exhibiting CTA-LTM. This can be explained by action of the cAMP-protein kinase A (PKA)cAMP response element-binding protein (CREB) pathway in the CGC (Nakamura et al., 1999b; Sadamoto et al., 2004, 2010, 2011; Wagatsuma et al., 2005, 2006). These results suggest that CGC-B1 synapses serve as a good model in which to elucidate how changes in synaptic transmission amplitude, for example, serve as a neural correlate of behavioral memory.

For the experiments with commercially available bovine insulin (Sigma-Aldrich) and the CNS factor solution, we stimulated the CGC for $2 \mathrm{~s}$ by the injection of depolarizing current into the neuron by a current- clamp method and recorded the compound EPSP in the B1 motor neuron. Because a single EPSP in the B1 motor neuron was very small $(<3$ $\mathrm{mV}$ ), we often failed to detect it depending on the preparation. We thus noticed a large compound EPSP in the B1 motor neuron. We adjusted the intensity of the injection current to the CGC on the initial trial in the normal Lymnaea saline to produce 9-11 spikes. This procedure was repeated three times to obtain an average EPSP amplitude. The bovine insulin was applied at the concentration of $5 \mu \mathrm{M}$. The stock solution of bovine insulin was prepared as $2 \mathrm{mg} / \mathrm{ml}$ (i.e., $349 \mu \mathrm{M}$ ) in $1 \mathrm{~mm} \mathrm{HCl}$, and thus the final concentration of $\mathrm{HCl}$ included in the bovine insulin solution was $14 \mu \mathrm{M}$. After incubation with $5 \mu \mathrm{M}$ bovine insulin in the Lymnaea saline for $15,30,45,60,75,90$, and $120 \mathrm{~min}$, we electrically stimulated the CGC for $2 \mathrm{~s}$ and recorded the compound EPSP in the B1 motor neuron. The intensity of electric stimulation was not changed for each CNS sample during a series of experiments. As the control experiments, we dissolved $14 \mu \mathrm{M} \mathrm{HCl}$ as the vehicle into the saline. The experiments for bovine insulin or the $\mathrm{HCl}$ control solution were performed in the chamber of $500 \mu \mathrm{l}$.

For the experiments using the CNS factor solution, we used a small chamber, $50 \mu$ l rather than the $500 \mu$ l chamber used in the bovine insulin experiments. That is, this $50 \mu \mathrm{l}$ solution included the secretions prepared from two CNSs. We incubated the isolated CNS with the CNS factor solution or the control solution to examine whether synaptic efficacy would change at the synapses between the CGC and the B1 motor neuron. The control solution used in this experimental set consisted of secretions from the CNSs without the cerebral ganglia.

To further confirm the effects of activation of MIP receptor on the synaptic efficacy between the CGC and the B1 motor neuron, we designed an experiment using insulin receptor antibody. We used mouse monoclonal [47-9] antibody to an insulin receptor $\alpha$ subunit (ab982; Abcam) for the following three reasons.

1. Insulin receptors are so homologous cross phyla, even in human (Jonas et al., 1996). In particular, ligand-binding sites are well conserved (see CAA59353 for Lymnaea, AAA59174 for human, and AAA39318 for mouse).

2 . The antibody used here was produced when human insulin receptor was used as the antigen (Soos et al., 1986).

3. This antibody recognizes the extracellular domain of human insulin receptor and acts as an antagonist. Thus, this antibody blocks the binding between insulin and human insulin receptor (Taylor et al., 1987).

Thus, we thought that this insulin receptor antibody is suitable for the blockade of MIP receptor in Lymnaea (Ito et al., 2012b). To block the function of MIP receptor, we incubated the isolated CNS with this insulin receptor antibody in Lymnaea saline at the final concentration of $25.6 \mu \mathrm{g} / \mathrm{ml}$ (175 $\mathrm{nM}$ ) for $90 \mathrm{~min}$ before the electrophysiological recording and changed this antibody solution to the CNS factor solution that still contained the antibody of $25.6 \mu \mathrm{g} / \mathrm{ml}$ ( $175 \mathrm{nM}$ ) for the electrophysiological experiments.

The experiments using the partially purified MIP solution were performed in a similar manner as those for the CNS factor solution. There were only three differences: (1) the recording chamber was coated with $5 \%$ bovine serum albumin (BSA); (2) $0.1 \%$ BSA was also applied to the CNS with the partially purified MIP solution; and (3) the concentration of an insulin receptor antibody in Lymnaea saline was $2.56 \mu \mathrm{g} / \mathrm{ml}(17.5$ $\mathrm{nM})$ because the concentration of partially purified MIPs was so low (100 nM) compared with that of bovine insulin $(5 \mu \mathrm{M})$. The first two procedures were performed to prevent MIPs from attaching to the plastic recording chambers. The application method for the insulin receptor antibody was the same.

To digest MIPs and other peptides in the CNS factor solution, we incubated the CNS factor solution with $10 \mu \mathrm{M}$ trypsin (T-1426; Sigma-Aldrich) at room temperature for $30 \mathrm{~min}$. Then we applied 100 $\mu \mathrm{M}$ trypsin inhibitor (from soybean; Wako) to the trypsin-treated solution to stop the action of trypsin, at room temperature for $10 \mathrm{~min}$. Such concentrations and durations of trypsin and trypsin inhibitor were decided by confirming that $5 \mu \mathrm{M}$ bovine insulin was digested with these chemicals. As a control experiment for a trypsin treatment, we applied only $100 \mu \mathrm{M}$ trypsin inhibitor to the CNS factor solution. This experiment was done to prove that a trypsin inhibitor did not affect the synaptic transmission. 
Previously, it was demonstrated using mammalian cell lines (i.e., HEK 293 and CHO cells) that the expressed Lymnaea MIP receptor was not cleaved into $\alpha$ and $\beta$ chains and it was autophosphorylated even in a nonligand bound state (Smit et al., 1998). These results were thought to have been due to incorrect processing and sorting of MIP receptor in the mammalian cells. In other words, the expressed structure of the MIP receptor is abnormal in a mammalian cell line. Thus, we cannot provide evidence for the binding of bovine insulin to the Lymnaea MIP receptor and the specificity of the antibody by expressing the Lymnaea MIP receptor in an exogenous mammalian cell line.

Training paradigm for taste aversion learning. To examine whether the insulin receptor antibody purchased commercially blocks behavioral LTM, we injected the insulin receptor antibody [final concentration of $2.56 \mu \mathrm{g} / \mathrm{ml}$ $(17.5 \mathrm{~nm})]$ in Lymnaea saline into the abdominal cavity of a snail. In this procedure, the total volume of this injection solution (i.e., antibody plus saline) was $40 \mu$ l. The calculated volume of hemolymph in a snail with a $20 \mathrm{~mm}$ shell length was $0.4 \mathrm{ml}$. One hour after injection of the antibody, the training, the pretest, and the posttests for LTM were performed in polystyrene Petri dishes (diameter, $35 \mathrm{~mm}$ ) (Sugai et al., 2006). All snails were first given a pretest. In this observation period ( $1 \mathrm{~min}$ ), the number of feeding responses (rasping movements of the buccal mass) was counted in distilled water after a $15 \mathrm{~s}$ application of $10 \mathrm{~mm}$ sucrose (the CS) to the lips of the snail. Taste aversion learning in Lymnaea was brought about by pairing the $10 \mathrm{~mm}$ sucrose CS and the $10 \mathrm{~mm} \mathrm{KCl} \mathrm{US.} \mathrm{The} \mathrm{duration} \mathrm{of} \mathrm{both} \mathrm{the} \mathrm{CS} \mathrm{and} \mathrm{the}$ US was $15 \mathrm{~s}$, with an interstimulus interval between the onsets of the CS and US of $15 \mathrm{~s}$. A $10 \mathrm{~min}$ intertrial interval was interposed between each pairing of the CS-US. Snails received 10 paired CS-US trials. The timing and duration of injection of the insulin receptor antibody are indicated in Results and in the figure legends.

We used a backward conditioning (US-CS) control group and a naive control group to validate associative learning. For the naive control group, only distilled water was applied to the lips instead of the CS and US. In the posttest sessions, snails were again challenged with the CS, and the number of bites was recorded in the 1 min interval in distilled water after a $15 \mathrm{~s}$ application of the CS. All tests were performed blindly. As a control for the insulin receptor antibody, we injected the saline or $1.92 \mu \mathrm{g}$ of mouse IgG (whole molecule; Jackson ImmunoResearch Laboratories) into the abdominal cavity. This weight was the same as that of the insulin receptor antibody.

Statistics. The data are expressed as mean \pm SEM. For the electrophysiological data, the significant difference at $p<0.05$ between two groups was examined by two-way repeated-measures ANOVA, and that between the data at each time point in two groups was examined by $t$ test. For the behavioral data, the significant difference was examined by one-way ANOVA and the post hoc Scheffé's test.

\section{Results}

\section{In situ hybridization of MIP II and MIP receptor}

The distribution of MIP II mRNA in the Lymnaea CNS has been shown previously (Meester et al., 1992; Smit et al., 1992), but that of the MIP receptor has not. With regard to the MIP receptor, only the deduced amino acids were reported (Roovers et al., 1995). We performed in situ hybridization for both MIP II and MIP receptor and compared their distributions (Figs. 1, 2).

As expected for MIP II, only the cells in the cerebral ganglia showed the in situ hybridization signals (Fig. $1 A$ ). On the basis of their size and position, we identified these cells as the neuroendocrine LGCs (as per Meester et al., 1992). When using the sense probe for MIP II, we did not find any in situ hybridization signals (Fig. $1 \mathrm{~B}$ ). In contrast to the results with MIP II signals, the in situ hybridization signals for the MIP receptor consisted of many pale purple "dots" that were found in neurons throughout the CNS (Fig. 2). The dots were localized around the nucleus of a cell body, e.g., the CGC (Fig. 2A), whereas no signal was observed for preparations using the sense probe (Fig. $2 B$ ). A similar pattern of signals (i.e., dots) was observed surrounding the nucleus of the B1 motor neuron (Fig. 2C). However, a positive signal was not observed in the neuropil regions (Fig. 2D). On the basis of these findings, we concluded that these dots represented the distribution of MIP receptor mRNA.

As we were most interested in determining whether insulin altered the ability of snails to learn and form memory (i.e., CTALTM), we paid particular attention to the buccal and the cerebral ganglia (Fig. $2 \mathrm{E}-\mathrm{H}$ ). We obtained positive signals for MIP receptor in the identified feeding motor neurons (B1, B2, and B3) in the buccal ganglia (Fig. 2E,F). The CGC and other neurons in the cerebral ganglia were also found to contain the MIP receptor mRNA (Fig. 2G). Control experiments using the sense probe did not show any positive signal in the cerebral ganglia (Fig. $2 \mathrm{H}$ ).

\section{Real-time PCR of MIP II and MIP receptor}

The in situ hybridization data showed that MIP II was only expressed in the cerebral ganglia, whereas MIP receptor was expressed throughout the entire CNS. Because the MIP receptor is a candidate receptor for all the MIPs including MIP II, and because MIPs are secreted in a hormone fashion, it is not surprising that the MIP receptor is expressed on neurons throughout the CNS.

To further confirm this assumption, we used real-time PCR for the quantification of these mRNAs (Fig. 3). We found that MIP II mRNA is localized to only the cerebral ganglia (Fig. 3A) and that the copy numbers in the other ganglia, including the 

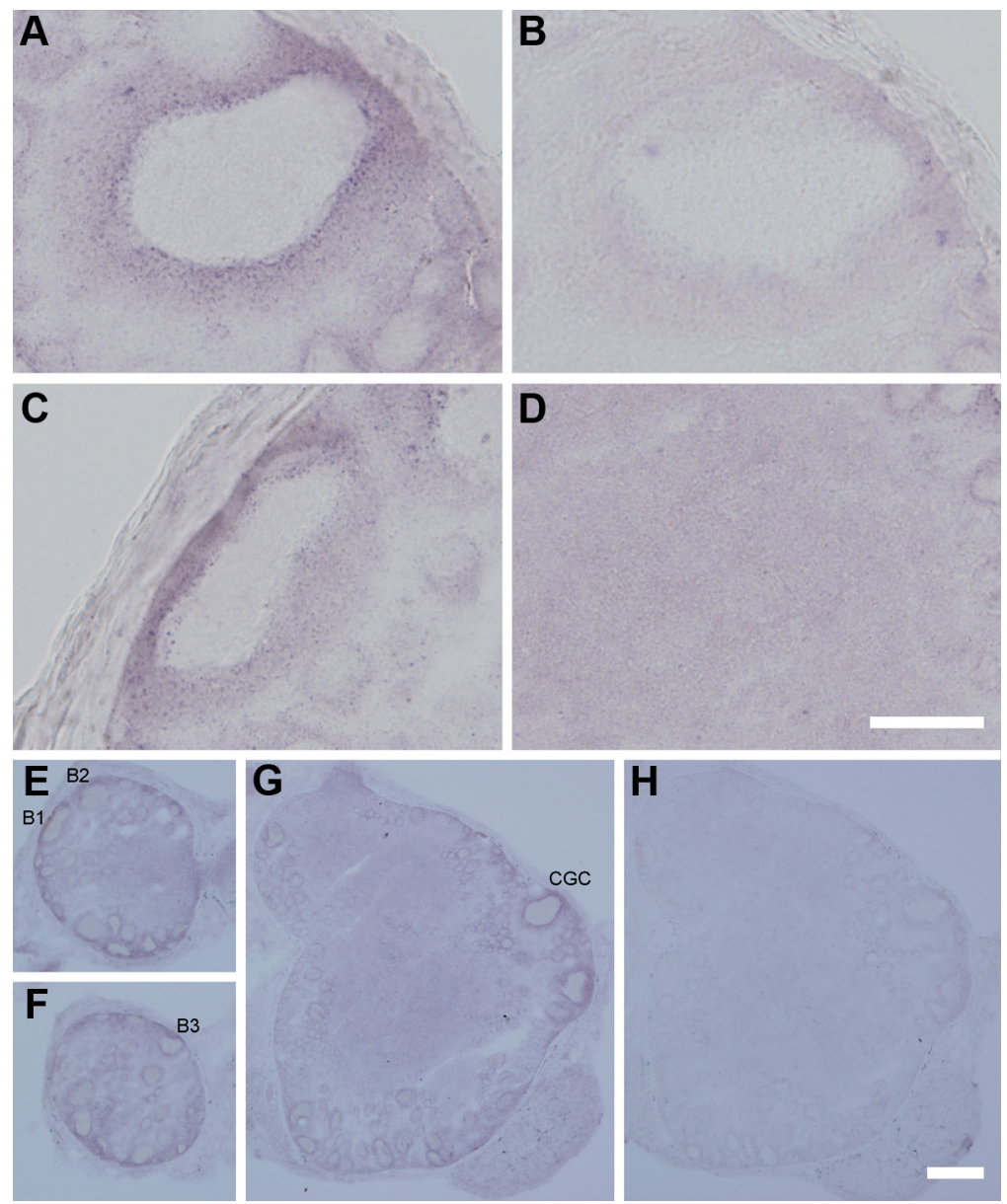

Figure 2. In situ hybridization of MIP receptor in the Lymnaea CNS. A, Photomicrograph of the CGC after exposure of the CNS to the antisense probe. The in situ hybridization signals appear as pale purple dots that were aggregated around the nucleus of the cell. $\boldsymbol{B}$, Photomicrograph of the CGC after exposure of the CNS to the sense probe. $\boldsymbol{C}$, Photomicrograph of the B1 motor neuron after exposure of the CNS to the antisense probe. The signals were also observed around the nucleus. D, Photomicrograph of the neuropil region after exposure of the CNS to the antisense probe. Positive signals were not observed. $\boldsymbol{E}, \boldsymbol{F}$, Photomicrographs of the buccal ganglion after exposure of the CNS to the antisense probe. Identifiable neurons such as the B1, B2, and B3 motor neurons, as well as numerous other neurons, are shown to contain the MIP receptor mRNA. G, Photomicrograph of the cerebral ganglion after exposure of the CNS to the antisense probe. The CGC and other neurons contained the MIP receptor mRNA. $\boldsymbol{H}$, Photomicrograph of the cerebral ganglion after exposure of the ganglion to the sense probe. Scale bars: $\boldsymbol{A}-\boldsymbol{D}, 50 \mu \mathrm{m} ; \boldsymbol{E}-\boldsymbol{H}, 200 \mu \mathrm{m}$.

buccal ganglia, are under our detection limit ( $<10$ copies; Fig. 3B; see Wagatsuma et al., 2005). In contrast, MIP receptor mRNA was in equal numbers in the cerebral and other ganglia, including the buccal ganglia (Fig. $3 A, C$ ). That is, we conclude that the MIP receptor is expressed throughout the CNS.

\section{Contents of secretions from the light green cells}

Because MIPs are synthesized and secreted from the LGCs in the cerebral ganglia (Meester et al., 1992; Smit et al., 1992), we attempted to obtain MIPs, including MIP I and II, by stimulation of the LGCs. We expected that the stimulation of the median lip nerves would result in the secretion of MIPs, including MIP I and II, into the recording chamber (see Materials and Methods). Thus, the solution in the chamber was referred to as the CNS factor solution. To determine whether MIPs were in the CNS factor solution, we focused on the stained bands between 3000 and 6000 molecular mass on the gel for the separation of molecules contained in the CNS factor solution.

MIPs in a reduction state are divided into two chains: A-chain of $3.0 \mathrm{kDa}$ and $\mathrm{B}$-chain of $3.9 \mathrm{kDa}$. We found a band of $\sim 4 \mathrm{kDa}$ only in the data for the CNS factor solution, and not in the con- trol solution (Fig. 4A). Here we note that the control solution was prepared as the secretion of the CNSs without the cerebral ganglia that were immersed in a small amount of Lymnaea saline. This band of 4 $\mathrm{kDa}$ is thought to correspond to the size of the $\mathrm{B}$-chain. The band of $3 \mathrm{kDa}$ corresponding to the size of the A-chain could not be observed (Fig. 4A). We think that the $3 \mathrm{kDa}$ peptide was so small that it was below the level of detection. We thus expected that MIPs are in the CNS factor solution.

In the tricine SDS-PAGE procedure, we also found a band of $\sim 4 \mathrm{kDa}$, but only in the lysate of the CNS that included the cerebral ganglia (i.e., LGCs present) and not in the control sample (i.e., LGCs not present; Fig. $4 \mathrm{~B}$ ). This band of $4 \mathrm{kDa}$ is thought to correspond to the B-chain of some MIPs. The $3 \mathrm{kDa}$ band corresponding to the A-chain could not be observed. We conclude that the small peptide secreted from the median lip nerves (Fig. $4 A$ ) is the same as that contained in the cerebral ganglia (Fig. 4B).

\section{Effects of insulin on long-term synaptic plasticity}

Our previous results showed that some MIP genes were upregulated in snails exhibiting "good" CTA-LTM (Azami et al., 2006). Here we examined the effects of MIPs and bovine insulin on synaptic plasticity in the Lymnaea CNS. In particular, we focused on changes in synaptic efficacy that occur at the CGC-B1 synapses (Nakamura et al., 1999b).

Because previous studies using another mollusc Aplysia demonstrated that application of $5 \mu \mathrm{M}$ bovine insulin activated the bag cell-neuron insulin receptor by stimulating its autophosphorylation on tyrosine residues (Jonas et al., 1996) and evoked the egg-laying hormone secretion (Jonas et al., 1997), we first used bovine insulin in our experiments to attempt to induce synaptic plasticity and then used the CNS factor solution (Fig. 5). Like insulin in vertebrates, MIPs are composed of two short amino acid chains, which are A-chain and B-chain linked by disulphide bridges, and its structure was thought to resemble that of bovine insulin (Kits et al., 1990; Li et al., 1992b).

When the CNS was incubated with $5 \mu \mathrm{M}$ bovine insulin, a significantly larger EPSP was found compared with the control ones (Fig. 5A; $p<0.05$, two-way repeated-measures ANOVA). The significantly larger EPSP was observed for at least $2 \mathrm{~h}$. This significantly larger and long-lasting increase in EPSP amplitude allowed us to conclude that a long-term change in synaptic efficacy occurred at the CGC-B1 synapses. In control experiments using just the vehicle, a significant increase in EPSP amplitude was not observed. The number of spikes evoked in the CGC over the course of the $2 \mathrm{~h}$ experiment decreased slightly in both the insulin and vehicle experiments (Fig. 5B). There were no signifi- 


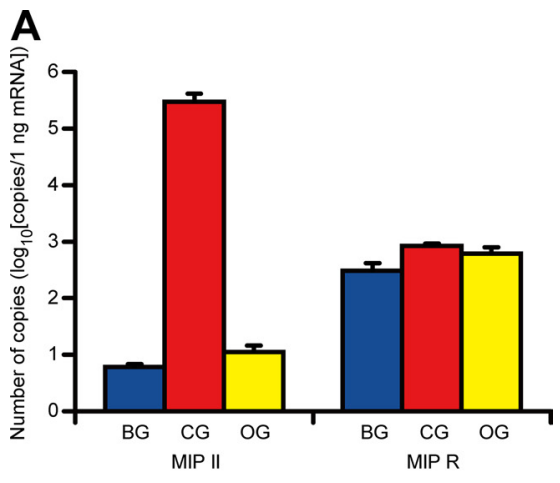

B
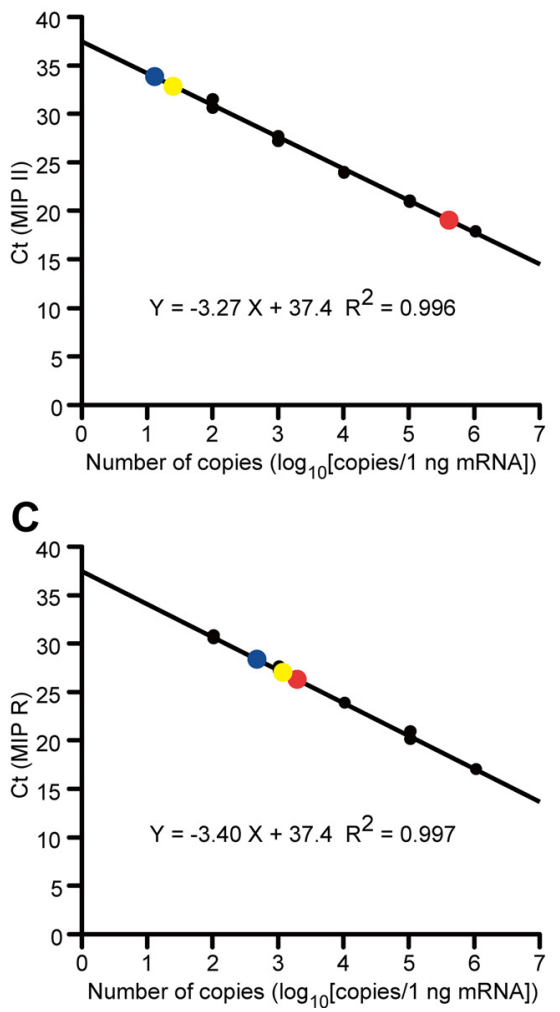

Figure 3. Determination of copy numbers of MIP II and MIP receptor in the Lymnaea CNS. A, Copy numbers of these two mRNAs in the specified ganglia. The MIP II mRNA was contained only in the cerebral ganglia, and the copy numbers in the buccal ganglia and the other ganglia were under the limit of our detection. The number of CNSs was four each. BG, Buccal ganglia; $C$, cerebral ganglia; OG, other ganglia. $\boldsymbol{B}$, Standard curve of MIP II mRNA by real-time PCR. $\boldsymbol{C}$, Standard curve of MIP receptor mRNA by real-time PCR. The $y$-axis shows the threshold cycle $(\mathrm{Ct})$ for real-time PCR. Black circles indicate the standard mRNA. The blue, red, and yellow circles show the median of the experimental data for the buccal ganglia, the cerebral ganglia, and the other ganglia, respectively.

cant differences in the number of spikes elicited in the bovine insulin and control experiments.

Next, we applied the CNS factor solution. Similar to what we observed with bovine insulin, there was a long-lasting increase in the amplitude of the EPSPs recorded in the B1 motor neurons (Fig. 5C).

In the control experiments, the compound EPSPs increased slightly over the course of the experiments (Fig. $5 C$ ). We found, however, that the increase in the EPSP amplitude by the CNS factor solution was statistically greater than by the control solution (Fig. $5 \mathrm{C} ; p<0.05$ by two-way repeated-measures ANOVA). Because the EPSPs sometimes evoked spikes in the B1 motor neurons after $75 \mathrm{~min}$, we show only data for $60 \mathrm{~min}$. As seen in Figure 4, both the CNS factor and the control solutions include many proteins, saccharides, and nucleotides. We think that these molecules increase the membrane excitability of the B1 motor neurons. In any case, both bovine insulin and the CNS factor solution alter synaptic efficacy at the CGC-B1 synapses.

When we incubated the isolated CNS with the insulin receptor antibody for $90 \mathrm{~min}$ before the electrophysiological experiments and added the CNS factor solution, the EPSP recorded in the B1 motor neurons was not enhanced but, rather, depressed (Fig. 5C; $p<0.05$, two-way repeated-measures ANOVA). That is, the insulin receptor antibody [25.6 $\mu \mathrm{g} / \mathrm{ml}(175 \mathrm{~nm})]$ blocked the longterm change in synaptic efficacy at the synapses that are probably involved in CTA-LTM.

The number of spikes elicited in the CGC over the course of the experiment did not change whether the CNS factor or the control solution was used (Fig. 5D). Together, we conclude that both bovine insulin and the CNS factor solution cause enhancement of the CGC-B1 synaptic connection. Moreover, the enhanced EPSP amplitude persists for at least $1 \mathrm{~h}$. Our preliminary experiments also showed that such a long-term synaptic change, which was caused by a 10 min application of bovine insulin, continued after washout of the solution.

Next, we digested MIPs and other peptides in the CNS factor solution by trypsin to show that trypsin-treated CNS factor solution does not induce a long-term synaptic change in the Lymnaea CNS. We prepared two solutions. The first one consisted of the CNS factor solution plus trypsin plus trypsin inhibitor. That is, we incubated the CNS factor solution with $10 \mu \mathrm{M}$ trypsin and applied $100 \mu \mathrm{M}$ trypsin inhibitor to stop the action of trypsin. The other one consisted of the CNS factor solution plus trypsin inhibitor. This solution was used for a control experiment to confirm that a trypsin inhibitor does not affect the synaptic transmission. As expected, when we used the CNS factor solution plus trypsin plus trypsin inhibitor, the CGC-B1 synaptic connection was not enhanced (Fig. 5E), whereas when we used the CNS factor solution plus trypsin inhibitor, the synaptic enhancement occurred. These data are consistent with our hypothesis that MIPs and possibly other proteins in the CNS factor solution are capable of inducing enhancement of the CGC-B1 synapses.

We then determined whether bovine insulin or the CNS factor solution altered the resting membrane potential or other intrinsic membrane properties of the CGC or the B1 motor neuron. With bath application of either bovine insulin or the CNS factor solution, no change was observed in either cell type.

\section{Effects of partially purified MIPs on long-term synaptic plasticity}

We partially purified MIPs from median lip nerve extracts. An acetic acid extract $(1 \mathrm{M})$ of median lip nerves was prepurified with the C18 extraction column and size fractionated using HPGPC (Fig. 6A). The fractions with the same elution position of bovine insulin were freeze-dried and rechromatographed using rpHPLC (Fig. 6B). Two peaks in a fraction eluted at 26-27 min after the injection were thought to contain MIP I and II based on the elution conditions of those peptides reported by Li et al. (1992a) (Fig. 6B, inset).

The two peaks in a fraction eluted at 26-27 min were analyzed independently by mass spectrometry (Fig. 6C, top and bottom, respectively). The molecular ion peak of the eluted peptide at 26 $\mathrm{min}$ in the spectrum was $6597.18(\mathrm{~m} / \mathrm{z}$ ) (Fig. 6C, top), and two ion peaks, 2502.97 and 3690.10 were obtained after cleaving disulfide bonds. Thus, we concluded that this peptide is MIP I 
A

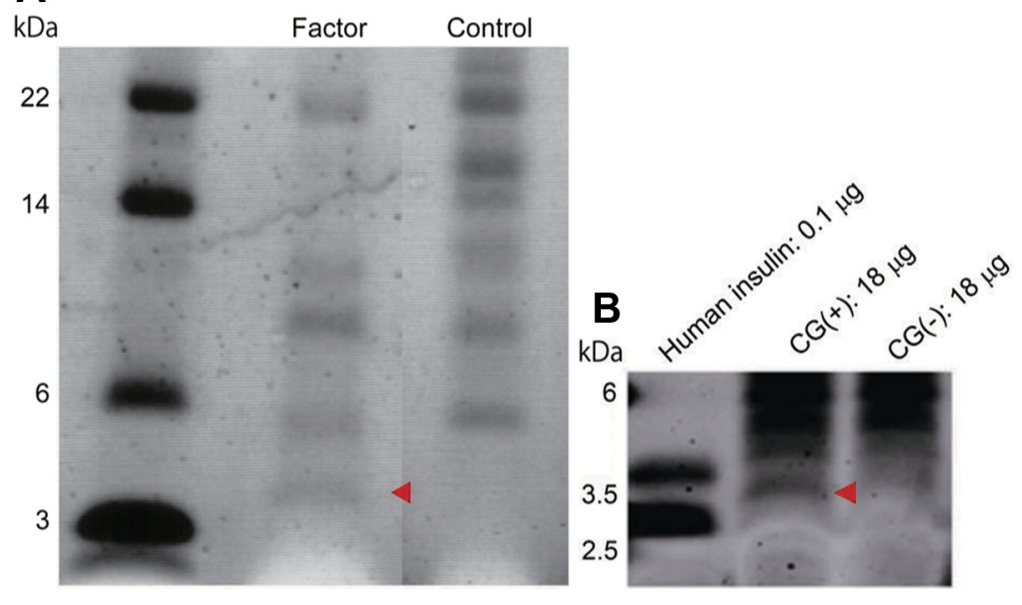

Figure 4. SDS-PAGE for CNS factor solution and control solution secreted from the Lymnaea CNS. A, NuPAGE electrophoresis. The left lane indicates the marker (molecular mass). The middle lane indicates the data for the CNS factor solution sample that was expected to include MIPs. The right lane indicates the data for the control solution sample. The band of $\sim 4 \mathrm{kDa}$ denoted by a red arrowhead can be observed in the CNS factor solution but not in the control solution. The control solution was prepared as the secretion of the CNSs without the cerebral ganglia that were immersed in a small amount of Lymnaea saline. This size corresponds to the B-chain of MIP II. B, Tricine SDS-PAGE. The left lane indicates the data for human insulin as a control. The middle lane indicates the data for the CNS factor solution sample that was expected to include MIPs. The right lane indicates the data for the control solution sample. Again, the band of $\sim 4 \mathrm{kDa}$ denoted by a red arrowhead can be observed in the CNS factor solution but not in the control solution.

compared with the calculated value from the MIP I, 6587.52. Three molecular ion peaks, 6156.14, 6591.09, and $6772.30(\mathrm{~m} / \mathrm{z})$, were observed at the eluted peptide of $27 \mathrm{~min}$ (Fig. $6 \mathrm{C}$, bottom). The values of 6591.09 and 6772.30 were close to those of MIP I (6587.52) and MIP III (6752.76). Thus, we concluded that this fraction contained mainly MIP I and III.

We called the above fraction obtained by rpHPLC "the MIP solution" (Fig. 6B), in which MIP I was identified by mass spectrometry (Fig. 6C), and we decided to use it for the additional electrophysiological studies. We thus applied the MIP solution to the isolated CNS and determined whether it caused the synaptic enhancement. Because the MIP receptor is known to be of one kind in Lymnaea (Roovers et al., 1995; Smit et al., 1998), any MIPs would bind to the MIP receptor. We thus expected that this MIP solution would enhance the EPSPs in the B1 motor neurons. Moreover, we expected that this enhancement would be blocked by the simultaneous application of insulin receptor antibody. Similar to what we observed with bovine insulin or with the CNS factor solution, there was a long-lasting increase in the amplitude of the EPSPs recorded in the B1 motor neurons with the MIP solution (Fig. 6D,E). After examination of various concentrations of the MIP solution, we found that application of $100 \mathrm{nM}$ MIP solution evoked long-term synaptic enhancement at the synapses between the CGCs and the B1 motor neurons. Finally, there was a significant difference between the data for the MIP solution and those for the MIP solution with the insulin receptor antibody $[2.56 \mu \mathrm{g} / \mathrm{ml}(17.5 \mathrm{nM})]$ or for the insulin receptor antibody only (Fig. $6 E$; $p<0.01$, two-way repeated-measures ANOVA) between the time of 0 and $60 \mathrm{~min}$.

\section{Effects of insulin receptor antibody on LTM consolidation}

If our hypothesis is correct that insulin-like molecules (i.e., MIPs) play a significant role in memory consolidation, we should be able to block LTM formation by using the insulin receptor antibody as we did in the synaptic enhancement experiments described above. First, however, we performed two control experiments. In these experiments, we injected saline $(0.04 \mathrm{ml})$ or $\operatorname{IgG}(1.92 \mu \mathrm{g}$ in $0.04 \mathrm{ml}$ of saline) into the abdominal cavity before taste aversion training. The amounts injected were adjusted to be the same as those described for the injection of the insulin receptor antibody [2.56 $\mu \mathrm{g} / \mathrm{ml}(17.5 \mathrm{~nm})]$

Sixty minutes after the injection of saline or IgG, we subjected the snails to the taste aversion training procedure (i.e., CS-US paired) and also prepared backward conditioning control (i.e., US-CS paired) and naive control snails (Fig. $7 A, B)$. In all groups of snails, a pretest to the CS (i.e., sucrose) was given and the number of bites per minute were ascertained. After the CS was paired 10 times with the US in the taste aversion training session, the feeding response to the CS was significantly reduced $(p<0.01$, onefactor ANOVA) at the $10 \mathrm{~min}$ posttest, compared with that observed when the backward conditioning control procedure was used or when only the distilled water was presented (naive control) (Fig. $7 A, B)$. This aversive behavior underwent consolidation into CTA-LTM, because the feeding response was still suppressed at the posttests of $1 \mathrm{~h}, 1 \mathrm{~d}$, and 1 week (Fig. 7 A,B).

We next injected the insulin receptor antibody into the snails $60 \mathrm{~min}$ before taste aversion training. In addition to this group of snails, we again used both a backward conditioning group and a naive group. A pretest to the CS was given in all three groups, and the number of bites per minute were recorded. There were no differences in the number of bites elicited by the CS in all three groups in the pretest $(p>0.05)$. After the taste aversion training, we found that the feeding response elicited by the CS in the posttest session (10 min later) of snails injected with the insulin receptor antibody was significantly reduced $(p<0.01$, one-way ANOVA followed by the post hoc Scheffe's test) compared with their pretest session and with the posttest sessions of the backward conditioning control or the naive control group (Fig. 7C). Thus, snails injected with the insulin receptor antibody were capable of learning and remembering for $10 \mathrm{~min}$.

Most importantly, however, there were no significant differences in the feeding response elicited by the CS in the posttest session ( $1 \mathrm{~h}$ later) compared with the pretest session in the insulin receptor antibody group $(p>0.05$; Fig. $7 C)$. In fact, the response elicited by the CS $1 \mathrm{~h}$ after training in this group was indistinguishable from that observed in either the backward conditioning or the naive control groups ( $p>0.05$; Fig. $7 C)$. Similarly, no differences were observed $1 \mathrm{~d}$ or 1 week later (Fig. 7C). That is, CTA-LTM was not observed in any of the three groups. Thus, the feeding response elicited by the CS $1 \mathrm{~h}$ after the taste aversion training returned to the initial level seen before the training.

We obtained similar data on the ability of the insulin receptor antibody to block the formation of LTM when we injected snails with the antibody $3 \mathrm{~h}$ before taste aversion training. We still had a significant suppression in the feeding response in the $10 \mathrm{~min}$ posttest session $(p<0.01)$, but $1 \mathrm{~h}$ later there was no difference in the feeding response compared with the pretest session (Fig. 7C).

Finally, we examined the possibility that the injection of the insulin receptor antibody evoked extinction of taste aversion in 
snails. Here we performed two experiments to test for extinction. First, both the injection period (60 $\mathrm{min}$ ) and concentration of insulin receptor antibody and the training paradigm were the same as those described above. However, we skipped the 10 min posttest to avoid that this CS could be an extinction session. We did not observe CTA-LTM in this experimental design (Fig. 7D). Second, we injected the insulin receptor antibody into snails in which CTA-LTM had already been consolidated. That is, the insulin receptor antibody was injected for $1 \mathrm{~h}$ into snails at the timing of $1 \mathrm{~h}$ after the taste aversion training was finished. In this experiment, LTM was observed. These data showed that once CTA-LTM was consolidated, the insulin receptor antibody did not affect recall (Fig. 7E). Thus, we believe that the injection of insulin receptor does not evoke the extinction of CTA-LTM. We conclude that taste aversion is acquired (i.e., learning) in the snails that are injected with the insulin receptor antibody but that the learning is not consolidated into LTM due to the action of the insulin receptor antibody.

\section{Discussion}

We hypothesized that some MIPs play a key role in the LTM consolidation process after the acquisition of taste aversion in Lymnaea. We tested this hypothesis at both the electrophysiological and behavioral levels. All of these data, as well as our anatomical data, are consistent with this hypothesis and add to the growing appreciation of the role played by insulin or insulin-like molecules in cognitive functioning.

\section{Blockade of LTM by insulin receptor antibody}

Our behavioral experiments showed that an injection of the insulin receptor antibody into the abdominal cavity did not inhibit the learning of taste aversion in Lymnaea. However, the data show that the insulin receptor antibody blocks the memory consolidation process; thus, CTA-LTM was not seen. This result was consistent with the electrophysiological data showing that synaptic enhancement caused by insulin or the secreted CNS factor (i.e., MIPs) could be blocked by the insulin receptor antibody. Together, the results reported here make a strong case for an insulin-like molecule having a causal role in LTM formation after taste aversion training.

In our taste aversion training paradigm, we used a 10-trial training proce-
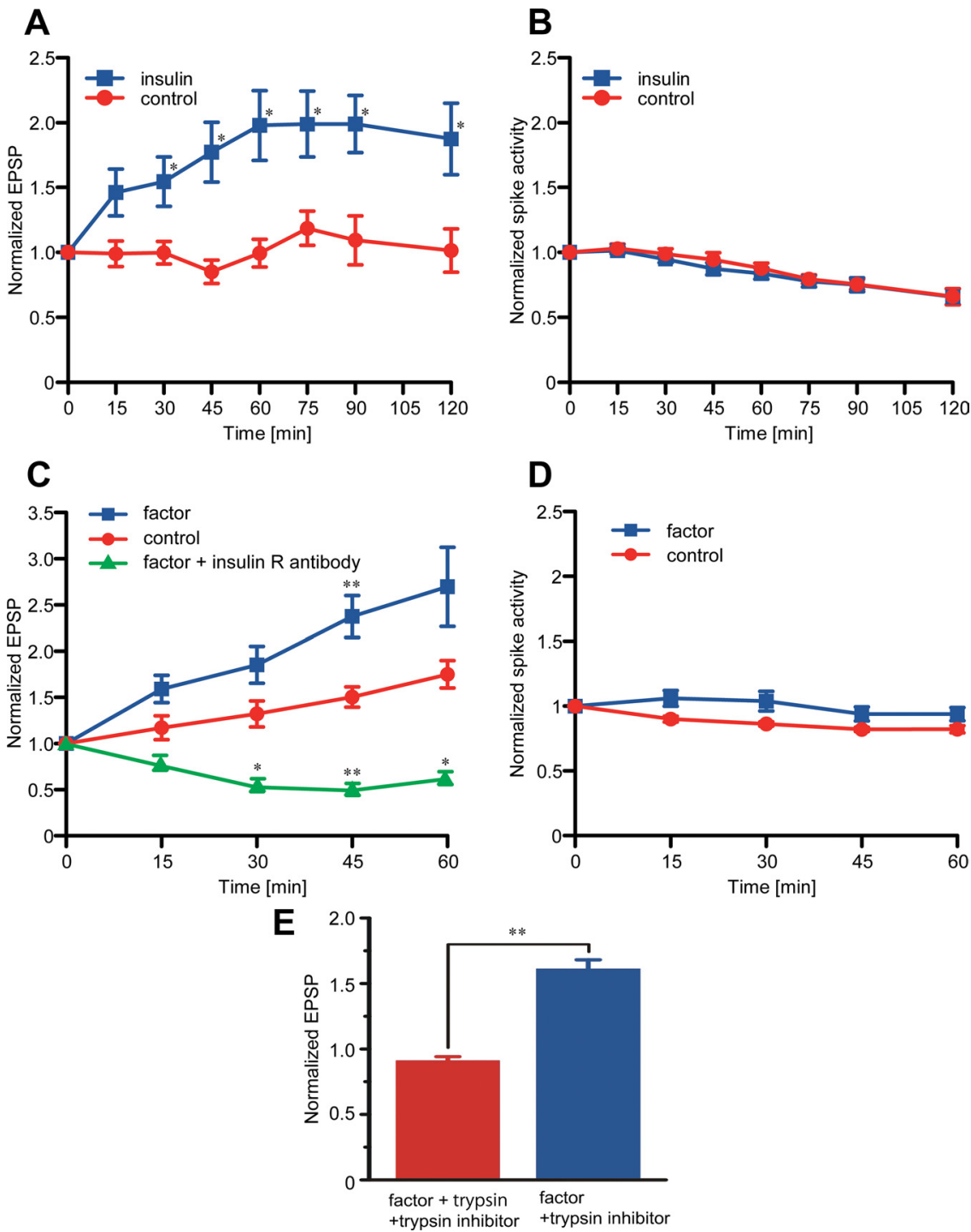

Figure 5. Change in long-term synaptic efficacy at synapses between the CGC and the B1 motor neuron in the isolated CNS of Lymnaea by application of mammalian insulin or the CNS factor solution. $\boldsymbol{A}$, Long-term synaptic enhancement evoked by application of $5 \mu \mathrm{m}$ bovine insulin. The $y$-axis shows the ratio between the EPSP recorded in the B1 motor neuron at the specified time and the EPSP at $0 \mathrm{~min}$. There is a significant difference between the data for bovine insulin and those for control ( $p<0.001$, two-way repeated-measures ANOVA). ${ }^{*} p<0.05, t$ test between the data for bovine insulin and those for control. The number of experiments for insulin and control was nine each. $\boldsymbol{B}$, Change in the number of spikes recorded in the CGCs. The $y$-axis shows the ratio between the number of spikes recorded in the CGCs at the specific time and the number of spikes at $0 \mathrm{~min}$. There are no significant differences between the data for bovine insulin and those for control. C, Long-term synaptic enhancement evoked by application of the CNS factor solution that included the secretion from the LGCs. The $y$-axis shows the ratio between the EPSP recorded in the B1 motor neuron at the specified time and the EPSP at $0 \mathrm{~min}$. There is a significant difference among the data for the CNS factor solution, those for the control solution and those for the CNS factor solution with the insulin receptor antibody ( $p<0.05$, two-way repeated-measures ANOVA) between the time of 0 and 60 min. ${ }^{*} p<0.05$ and ${ }^{* *} p<0.01$ by $t$ test, respectively, between the data for the control solution and those for the control solution and between the data for the CNS factor solution and those for the CNS factor solution with insulin receptor antibody [its final concentration of $25.6 \mu \mathrm{g} / \mathrm{ml}(175 \mathrm{~nm})$ ]. The number of experiments for the CNS factor solution and the control solution was five each. That for the CNS factor solution with insulin receptor antibody was six. One trial of a solution included the secretions from the two CNSs. D, No change in the number of spikes recorded in the CGCs. The $y$-axis shows the ratio between the number of spikes recorded in the CGCs at the specific time and the number of spikes at $0 \mathrm{~min}$. There were no significant differences between the data for the CNS factor solution and those for the control solution. $\boldsymbol{E}$, No induction of long-term synaptic enhancement by the trypsin-treated CNS factor solution. The $y$-axis shows the ratio between the EPSP recorded in the B1 motor neuron at $60 \mathrm{~min}$ and the EPSP at $0 \mathrm{~min}$. There is a significant difference between the data for the CNS factor solution plus trypsin plus trypsin inhibitor and that for the CNS factor solution plus trypsin inhibitor ( ${ }^{* *} p<0.01, t$ test between them). The number of experiments for the CNS factor solution plus trypsin plus trypsin inhibitor and the CNS factor solution plus trypsin inhibitor was three and five, respectively. One trial of a solution included the secretions from the two CNSs. 

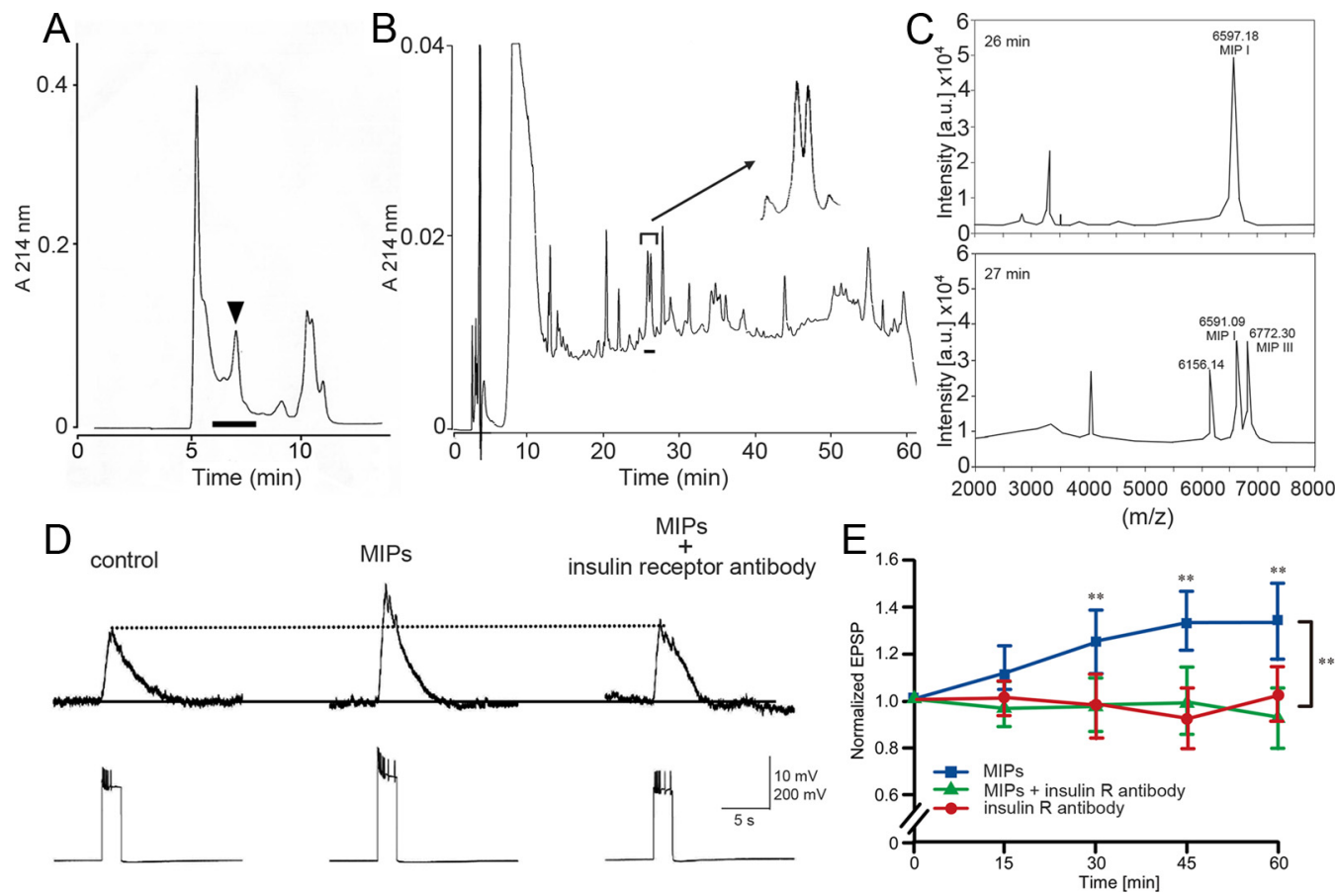

Figure 6. Long-term synaptic efficacy at synapses between the CGC and the B1 motor neuron in the isolated CNS of Lymnaea by application of partially purified MIP solution. A, An HPGPC chromatograph of $1 \mathrm{~m}$ acetic acid extract of median lip nerves. The arrowhead indicates the elution position of bovine insulin. The fractions denoted by the bar were further purified using rpHPLC. $\boldsymbol{B}$, An rpHPLC chromatograph of the median lip nerve extracts after partial purification with HPGPC. Two peaks denoted by the bar were thought to contain MIP I and II (see inset). C, Mass spectrometry (MALDI-TOF/TOF) proteomic analysis of partially purified MIPs. The first peak and the second one of the two peaks in a fraction eluted at $26-27$ min (see $\boldsymbol{B}$ ) were analyzed independently by MALDI-TOF/TOF mass spectrometry (top and bottom, respectively). Top, Mass spectrum of the rpHPLC eluted peptide at 26 min showed a molecular ion peak 6597.18 ( $\mathrm{m} / \mathrm{z}$ ). This peptide is MIP I compared with the calculated value from the MIP I, 6587.52. Bottom, Mass spectrum of the rpHPLC eluted peptide at 27 min showed three ion peaks of 6156.14, 6591.09, and 6772.30 ( $\mathrm{m} / \mathrm{z}$ ). The values of 6591.09 and 6772.30 were close to those of MIP I (6587.52) and MIP III (6752.76). D, Long-term synaptic enhancement evoked by application of $100 \mathrm{~nm}$ MIP solution including mainly MIP I. Typical recordings of evoked compound B1 EPSPs. Top, Recordings of evoked compound B1 EPSPs. Bottom, Recordings of spikes of the CGCs. Control, Recording from the isolated CNS before application of MIP solution; MIPs, recording from the isolated CNS after application of $100 \mathrm{~nm}$ MIP solution for $45 \mathrm{~min}$; MIPs + insulin receptor antibody, recording from the isolated CNS after application of $100 \mathrm{~nm}$ MIP solution with $17.5 \mathrm{~nm}$ insulin receptor antibody for $60 \mathrm{~min}$. E, Summary of change in EPSPs by application of $100 \mathrm{~nm} \mathrm{MIP} \mathrm{solution,} \mathrm{by} \mathrm{application} \mathrm{of} 100 \mathrm{~nm}$ MIP solution with $17.5 \mathrm{~nm}$ insulin receptor antibody, and by application of $17.5 \mathrm{~nm}$ insulin receptor antibody only. The $y$-axis shows the ratio between the EPSP recorded in the B1 motor neuron at the specified time and the EPSP at $0 \mathrm{~min}$. There is a significant difference among the data for MIP solution and those for MIP solution with insulin receptor antibody ( $p<0.01$, two-way repeated-measures ANOVA) between the time of 0 and $60 \mathrm{~min} .{ }^{* *} p<0.01$, between the data for MIP solution and those for MIP solution with insulin receptor antibody or those for insulin receptor antibody only. The number of experiments for MIP solution was eight. That for MIP solution with insulin receptor antibody was seven. That for the insulin receptor antibody only was six.

dure. That is, when we tested the taste aversion trained snails at the $10 \mathrm{~min}$ posttest, $100 \mathrm{~min}$ had indeed passed after the onset of taste aversion training. Furthermore, when we tested the taste aversion trained snails $1 \mathrm{~h}$ later, $150 \mathrm{~min}$ had passed. These data suggest that the consolidation period for LTM occurs $\sim 2$ or $3 \mathrm{~h}$ later after the onset of taste aversion training in Lymnaea. Recent experiments using a one-trial training procedure followed by a quick cooling treatment $\left(4^{\circ} \mathrm{C}\right.$ for $\left.30 \mathrm{~min}\right)$ showed that cooling must be performed within 10 min after the training onset to block both taste aversion learning and its LTM formation (Sugai et al., 2007). However, after taste aversion learning is acquired, we do not know when LTM underwent memory consolidation. Based on the data presented here, it is reasonable to believe that the consolidation period for CTA-LTM in Lymnaea occurs 2 or $3 \mathrm{~h}$ later after the training onset. These data are similar to those reported previously (Matsumoto et al., 2009; Amano and Maruyama, 2011; Braun and Lukowiak, 2011; Michel et al., 2011; Trannoy et al., 2011).

\section{Do good learners constitutionally contain more MIPs than poor learners?}

Correlational studies using CTA in Lymnaea had previously identified a possible role of MIPs in LTM formation. Azami et al. (2006) found that in so-called "good" learners, but not "poor" learners, that some of the upregulated genes found in the CNS were the genes encoding MIPs. Although they referred to snails that showed LTM as good learners, it probably would have been more appropriate to call them snails with good memory, because that was what they were measuring. Semantics aside, what those data suggested was that in snails possessing LTM for CTA, there was a correlated increase with activity of the genes that encode MIPs.

It is a still unresolved question as to whether MIPs in Lymnaea also play an important and/or necessary role in the memoryforming processes after other training procedures. It is tempting to speculate that MIPs play a role in appetitive food conditioning (Straub et al., 2006), because many of the same neuronal pathways are involved as in CTA.

Also unresolved is whether MIPs only play a permissive role in the consolidation process. That is, secretion of MIPs is not tied to the actual training procedure but rather MIPs are continually being synthesized and released. If MIPs are not present, consolidation does not occur. However, whether there is an increase in MIP synthesis or release as a result of the training procedure is not known. We do know that the genes encoding MIPs are upregulated in good learners (i.e., snails that exhibit good memory; Azami et al., 2006). However, it is possible that in the poor learners that in the naive state MIP levels were down. In other words, 

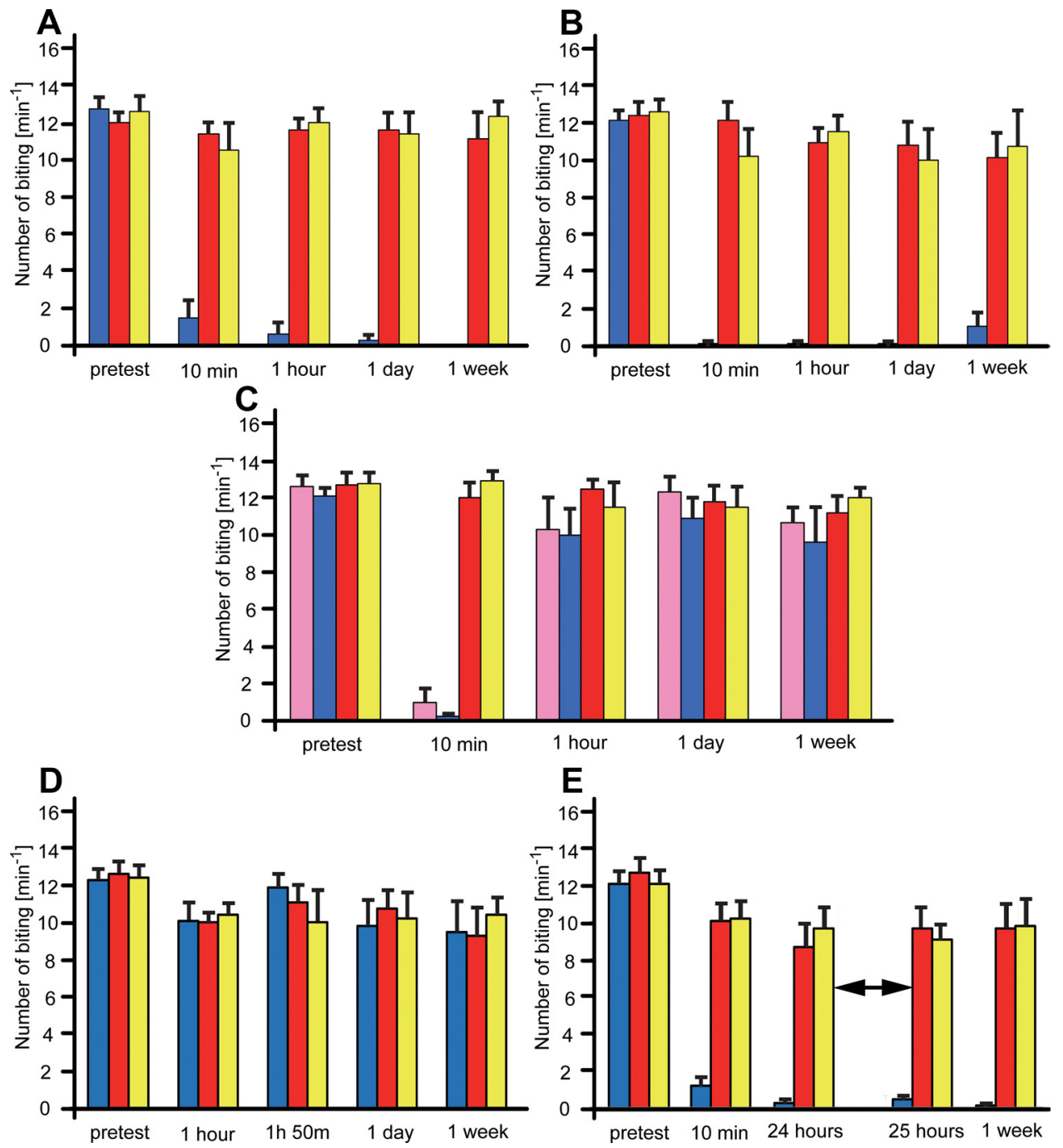

Figure 7. Effects of insulin receptor antibody on taste aversion learning and its CTA-LTM in snails. $A$, Injection of saline. The saline ( $0.04 \mathrm{ml})$ was injected into the abdominal cavity as the control for insulin receptor antibody. After a 60 min injection, we prepared taste aversion-trained snails (blue bars), backward conditioned snails (red bars), and naive control snails (yellow bars). The $y$-axis shows the numbers of bites per minute elicited by the $C S$ (sucrose) in the pretest session and the posttest sessions. The time indicated in the $x$-axis shows that for the posttest session, that was performed after the training. After the CS was paired 10 times with the US in the taste aversion training session, the feeding response to the CS was significantly reduced ( $p<0.01$, one-factor ANOVA and post hoc Scheffé's test) at the posttest of $10 \mathrm{~min}$, compared with those observed for the backward conditioned and naive control snails. This aversive behavior was consolidated to (TA-LTM that was recorded at the posttests of $1 \mathrm{~h}, 1 \mathrm{~d}$, and 1 week. $\boldsymbol{B}$, Injection of $\mathrm{lgG}$. The $\operatorname{lgG}(1.92 \mu \mathrm{g})$ was injected into the abdominal cavity as the control for insulin receptor antibody. After a 60 min injection and the training, the feeding response to the CS was also significantly reduced ( $p<0.01$, one-factor ANOVA and post hoc Scheffé's test) at the posttest of 10 min, compared with those observed for the backward conditioned and naive control snails. This aversive behavior was also consolidated to CTA-LTM that was recorded at the posttests of $1 \mathrm{~h}, 1 \mathrm{~d}$, and 1 week. C, Injection of insulin receptor antibody for $60 \mathrm{~min}$ or $3 \mathrm{~h}$ before taste aversion training. The insulin receptor antibody, whose final concentration was $2.56 \mu \mathrm{g} / \mathrm{ml}$ ( $17.5 \mathrm{~nm}$ ) in Lymnaea saline, was injected for 60 min (blue bars) or $3 \mathrm{~h}$ (pink bars) before the pretest. The CS-elicited feeding response after the training in taste aversion-trained snails, which was injected in the insulin receptor antibody for $60 \mathrm{~min}$ or $3 \mathrm{~h}$, was significantly less ( $p<0.01$, one-way ANOVA followed by the post hoc Scheffé's test) than in either snails given backward conditioning or naive control. However, there were no significant differences in the elicited feeding response among the three groups (i.e., taste aversion, backward, and naive) at the posttest sessions that were performed $1 \mathrm{~h}, 1 \mathrm{~d}$, and 1 week later. The red and yellow bars indicate backward conditioning control and naive control snails, respectively. $\boldsymbol{D}$, Injection of insulin receptor antibody for 60 min before taste aversion training. The timing of injection of insulin receptor antibody and the training paradigm were the same as those shown by blue bars in C. However, we skipped the posttest of 10 min to avoid that this CS would become an extinction stimulus. There were no significant differences in the elicited feeding response among all the data. E, Injection of insulin receptor antibody for $60 \mathrm{~min}$ between the posttests of 24 and $25 \mathrm{~h}$ after taste aversion training. Without any injection of drugs, we started taste aversion training. We observed CTA-LTM at the posttests of $10 \mathrm{~min}$ and $24 \mathrm{~h}$ (blue bars; $p<0.01$, one-way ANOVA followed by the post hoc Scheffe's test). We then injected the insulin receptor antibody for $60 \mathrm{~min}$ (left-right arrow) to examine whether this antibody would enhance the extinction of (TA-LTM. The suppressed feeding response was still observed at the posttests of $25 \mathrm{~h}$ and 1 week. Each bar consists of the data obtained from 10 snails.

there was a difference in MIP gene activity before any training occurred. We do know in Lymnaea that there are different innate abilities to form LTM after training. Some snails show enhanced memory formation while others do not, and that difference is heritable (Orr et al., 2009; Dalesman and Lukowiak, 2010). It could very well be that differences in ongoing MIP gene activity could be a possible explanation for this experimental finding. Studies now underway will test this possibility in the different strains of Lymnaea that exhibit differing cognitive abilities.

\section{Insulin and memory in other animals}

It is becoming clear that insulin plays an important role in cognitive functioning in animals, including humans. Insulin receptors are found in abundance on neurons in the hippocampus, the entorhinal cortex, and the frontal cortex all areas important for memory formation and retrieval (Chiu et al., 2008; McNay et al., 2010). Moreover, a recent clinical study shows promise of using intranasal insulin administration in the treatment of Alzheimer's disease (Craft et al., 2012). Previous reports have also indicated 
that insulin or insulin-like peptides play key roles in the process of memory formation, as, for example, in Caenorhabditis elegans, rodents, and humans (Wu et al., 1999; Zhao et al., 1999; Izquierdo et al., 2000; Dou et al., 2005; Murakami et al., 2005; Ramsey et al., 2005; Tomioka et al., 2006; Haj-ali et al., 2009; Oda et al., 2011; Smith et al., 2011).

Insulin binding to the insulin receptor leads to intracellular recruitment of insulin receptor substrates and activation of phosphoinositide 3-kinase signaling, which is implicated in both the induction and maintenance of long-term potentiation and longterm depression in hippocampal slices (Sanna et al., 2002; Kim et al., 2011). Furthermore, because the growth hormone/insulinlike growth factor-I axis is involved in the regulation of brain growth and development (Chiu et al., 2008; Aberg, 2010), these factors are well positioned to be used for the remodeling of synapses or other morphological changes that are part of the memory-forming process.

\section{Possible function of MIPs in a long-term synaptic enhancement}

We previously demonstrated that the injection of cAMP into the CGC brought about a long-lasting change in synaptic plasticity at the CGC-B1 synapses (Nakamura et al., 1999b). The existence of activator and repressor types of CREB, CREB1 and CREB2, has also been demonstrated in the CGCs and other neurons (Ribeiro et al., 2003; Sadamoto et al., 2004, 2010, 2011; Wagatsuma et al., 2005, 2006). Moreover, prior injection of the CRE oligonucleotide or a PKA inhibitor into the CGC blocked the expression of this long-lasting change in synaptic plasticity at the CGC-B1 synapses (Nakamura et al., 1999b; Sadamoto et al., 2004). CREBs have been thought to play an important role in this long-lasting change in synaptic plasticity at the "presynaptic" sites. Whether MIPs also act at the presynaptic or postsynaptic site is still to be determined.

In culture neurons of GABA-mediated networks, application of insulin increased the expression of the $\mathrm{GABA}_{\mathrm{A}}$ receptor on the postsynaptic membranes of these neurons (Wan et al., 1997). Insulin may evoke a rapid recruitment of functional $\mathrm{GABA}_{\mathrm{A}}$ receptors to the postsynaptic plasma membrane, suggesting a fundamental mechanism for the generation of synaptic plasticity. At the CGC-B1 synapses in Lymnaea, serotonin appears to be the likely transmitter substance (Nakamura et al., 1999b), so it is possible that MIPs could result in an increase in serotonin receptors on the $\mathrm{B} 1$ motor neurons. This possibility is currently being examined.

\section{Other functions of MIPs}

The MIP genes are also expressed in the canopy cells in the lateral lobe near the cerebral ganglia (Smit et al., 1988). The canopy cells, as well as the LGCs, control body growth (Geraerts, 1976a, b). In both the canopy cells and the LGCs, complement receptor 3-like immunoreactivity is also detected (Hatakeyama et al., 2000). However, the exact function of MIPs and complement receptor 3 in the canopy cells is still unknown. Furthermore, MIP VII gene is known to be expressed in the buccal ganglia (Smit et al., 1996). MIP VII might be involved in feeding behavior. Our present findings do not exclude the possibility that MIPs other than MIP I, II, and III from the LGCs and even from the canopy cells play an important role in the establishment of the neural correlates of behavioral LTM. MIP II is known to stimulate neurite formation (Smit et al., 1988; Kits et al., 1990).

In conclusion, the present data are consistent with the hypothesis that MIPs secreted from the LGCs play an important and necessary role in the formation of LTM after the acquisition of associative learning (i.e., CTA). This conclusion is consistent with the hypothesis that insulin or insulin-like molecules play an important role in cognitive functions in animals, including humans. The Lymnaea model system then can serve as a test bed to determine the causal mechanisms of how insulin or insulin-like molecules exert their effects on cognition.

\section{References}

Aberg D (2010) Role of the growth hormone/insulin-like growth factor 1 axis in neurogenesis. Endocr Dev 17:63-76. Medline

Amano H, Maruyama IN (2011) Aversive olfactory learning and associative long-term memory in Caenorhabditis elegans. Learn Mem 18:654-665. CrossRef Medline

Azami S, Wagatsuma A, Sadamoto H, Hatakeyama D, Usami T, Fujie M, Koyanagi R, Azumi K, Fujito Y, Lukowiak K, Ito E (2006) Altered gene activity correlated with long-term memory formation of conditioned taste aversion in Lymnaea. J Neurosci Res 84:1610-1620. CrossRef Medline

Benjamin PR, Rose RM, Slade CT, Lacy MG (1979) Morphology of identified neurones in the buccal ganglia of Lymnaea stagnalis. J Exp Biol 80:119-135.

Benjamin PR, Staras K, Kemenes G (2000) A systems approach to the cellular analysis of associative learning in the pond snail Lymnaea. Learn Mem 7:124-131. CrossRef Medline

Braun MH, Lukowiak K (2011) Intermediate and long-term memory are different at the neuronal level in Lymnaea stagnalis (L.). Neurobiol Learn Mem 96:403-416. CrossRef Medline

Chiu SL, Chen CM, Cline HT (2008) Insulin receptor signaling regulates synapse number, dendritic plasticity, and circuit function in vivo. Neuron 58:708-719. CrossRef Medline

Craft S, Baker LD, Montine TJ, Minoshima S, Watson GS, Claxton A, Arbuckle M, Callaghan M, Tsai E, Plymate SR, Green PS, Leverenz J, Cross D, Gerton B (2012) Intranasal insulin therapy for Alzheimer disease and amnestic mild cognitive impairment: a pilot clinical trial. Arch Neurol 69:29-38. CrossRef Medline

Dalesman S, Lukowiak K (2010) Effect of acute exposure to low environmental calcium on respiration and locomotion in Lymnaea stagnalis (L.). J Exp Biol 213:1471-1476. CrossRef Medline

Dou JT, Chen M, Dufour F, Alkon DL, Zhao WQ (2005) Insulin receptor signaling in long-term memory consolidation following spatial learning. Learn Mem 12:646-655. CrossRef Medline

Elliott CJ, Vehovszky A (2000) Comparative pharmacology of feeding in molluscs. Acta Biol Hung 51:153-163. Medline

Fukuyama Y, Iwamoto S, Tanaka K (2006) Rapid sequencing and disulfide mapping of peptides containing disulfide bonds by using 1,5diaminonaphthalene as a reductive matrix. J Mass Spectrom 41:191201. Medline

Geraerts WP (1976a) Control of growth by the neurosecretory hormone of the light green cells in the freshwater snail Lymnaea stagnalis. Gen Comp Endocrinol 29:61-71. CrossRef Medline

Geraerts WP (1976b) The role of the lateral lobes in the control of growth and reproduction in the hermaphrodite freshwater snail Lymnaea stagnalis. Gen Comp Endocrinol 29:97-108. CrossRef Medline

Haj-ali V, Mohaddes G, Babri SH (2009) Intracerebroventricular insulin improves spatial learning and memory in male Wistar rats. Behav Neurosci 123:1309-1314. CrossRef Medline

Hatakeyama D, Ito I, Kojima S, Fujito Y, Ito E (2000) Complement receptor 3 -like immunoreactivity in the light green cells and the canopy cells of the pond snail, Lymnaea stagnalis. Brain Res 865:102-106. CrossRef Medline

Inda MC, Delgado-García JM, Carrión AM (2005) Acquisition, consolidation, reconsolidation, and extinction of eyelid conditioning responses require de novo protein synthesis. J Neurosci 25:2070-2080. CrossRef Medline

Ito E, Kobayashi S, Kojima S, Sadamoto H, Hatakeyama D (1999) Associative learning in the pond snail, Lymnaea stagnalis. Zool Sci 16:711-723. CrossRef

Ito E, Otsuka E, Hama N, Aonuma H, Okada R, Hatakeyama D, Fujito Y, Kobayashi S (2012a) Memory trace in feeding neural circuitry underlying conditioned taste aversion in Lymnaea. PLoS One 7:e43151. CrossRef Medline 
Ito E, Okada R, Sakamoto Y, Otshuka E, Mita K, Okuta A, Sunada H, Sakakibara M (2012b) Insulin and memory in Lymnaea. Acta Biol Hung 63 [Suppl 2]:320-327.

Izquierdo LA, Barros DM, Ardenghi PG, Pereira P, Rodrigues C, Choi H, Medina JH, Izquierdo I (2000) Different hippocampal molecular requirements for short- and long-term retrieval of one-trial avoidance learning. Behav Brain Res 111:93-98. CrossRef Medline

Jonas EA, Knox RJ, Kaczmarek LK, Schwartz JH, Solomon DH (1996) Insulin receptor in Aplysia neurons: characterization, molecular cloning, and modulation of ion currents. J Neurosci 16:1645-1658. Medline

Jonas EA, Knox RJ, Smith TC, Wayne NL, Connor JA, Kaczmarek LK (1997) Regulation by insulin of a unique neuronal $\mathrm{Ca}^{2+}$ pool and of neuropeptide secretion. Nature 385:343-346. CrossRef Medline

Kawai R, Kobayashi S, Fujito Y, Ito E (2011) Multiple subtypes of serotonin receptors in the feeding circuit of a pond snail. Zool Sci 28:517-525. CrossRef Medline

Kemenes G, Benjamin PR (2009) Lymnaea. Curr Biol 19:R9-R11. CrossRef Medline

Kim JI, Lee HR, Sim SE, Baek J, Yu NK, Choi JH, Ko HG, Lee YS, Park SW, Kwak C, Ahn SJ, Choi SY, Kim H, Kim KH, Backx PH, Bradley CA, Kim E, Jang DJ, Lee K, Kim SJ, et al. (2011) PI3K $\gamma$ is required for NMDA receptor-dependent long-term depression and behavioral flexibility. Nat Neurosci 14:1447-1454. CrossRef Medline

Kits KS, de Vries NJ, Ebberink RH (1990) Molluscan insulin-related neuropeptide promotes neurite outgrowth in dissociated neuronal cell cultures. Neurosci Lett 109:253-258. CrossRef Medline

Kojima S, Yamanaka M, Fujito Y, Ito E (1996) Differential neuroethological effects of aversive and appetitive reinforcing stimuli on associative learning in Lymnaea stagnalis. Zool Sci 13:803-812. CrossRef

Kojima S, Nanakamura H, Nagayama S, Fujito Y, Ito E (1997) Enhancement of an inhibitory input to the feeding central pattern generator in Lymnaea stagnalis during conditioned taste-aversion learning. Neurosci Lett 230:179-182. CrossRef Medline

Kojima S, Hosono T, Fujito Y, Ito E (2001) Optical detection of neuromodulatory effects of conditioned taste aversion in the pond snail Lymnaea stagnalis. J Neurobiol 49:118-128. CrossRef Medline

Kyriakides MA, McCrohan CR (1989) Effect of putative neuromodulators on rhythmic buccal motor output in Lymnaea stagnalis. J Neurobiol 20: 635-650. CrossRef Medline

Lee YS, Bailey CH, Kandel ER, Kaang BK (2008) Transcriptional regulation of long-term memory in the marine snail Aplysia. Mol Brain 1:3. CrossRef Medline

Li KW, Geraerts WP, Ebberink RH, Joosse J (1992a) Purification and sequencing of molluscan insulin-related peptide I (MIP I) from the neuroendocrine light green cells of Lymnaea stagnalis. Mol Cell Endocrinol 85:141-150. CrossRef Medline

Li KW, Geraerts WP, Joosse J (1992b) Purification and sequencing of molluscan insulin-related peptide II from the neuroendocrine light green cells in Lymnaea stagnalis. Endocrinology 130:3427-3432. CrossRef Medline

Li KW, Geraerts WP, van Loenhout H, Joosse J (1992c) Biosynthesis and axonal transport of multiple molluscan insulin-related peptides by the neuroendocrine light green cells of Lymnaea stagnalis. Gen Comp Endocrinol 87:79-86. CrossRef Medline

Lukowiak K, Martens K, Rosenegger D, Browning K, de Caigny P, Orr M (2008) The perception of stress alters adaptive behaviours in Lymnaea stagnalis. J Exp Biol 211:1747-1756. CrossRef Medline

Matsumoto Y, Hatano A, Unoki S, Mizunami M (2009) Stimulation of the cAMP system by the nitric oxide-cGMP system underlying the formation of long-term memory in an insect. Neurosci Lett 467:81-85. CrossRef Medline

Matsuo R, Ito E (2009) A novel nitric oxide synthase expressed specifically in the olfactory center. Biochem Biophys Res Commun 386:724-728. CrossRef Medline

McCrohan CR, Benjamin PR (1980) Synaptic relationships of the cerebral giant cells with motor neurones in the feeding system of Lymnaea stagnalis. J Exp Biol 85:169-186. Medline

McNay EC, Ong CT, McCrimmon RJ, Cresswell J, Bogan JS, Sherwin RS (2010) Hippocampal memory processes are modulated by insulin and high-fat-induced insulin resistance. Neurobiol Learn Mem 93:546-553. CrossRef Medline

Meester I, Ramkema MD, van Minnen J, Boer HH (1992) Differential ex- pression of four genes encoding molluscan insulin-related peptides in the central nervous system of the pond snail Lymnaea stagnalis. Cell Tissue Res 269:183-188. CrossRef Medline

Michel M, Green CL, Eskin A, Lyons LC (2011) PKG-mediated MAPK signaling is necessary for long-term operant memory in Aplysia. Learn Mem 18:108-117. CrossRef Medline

Murakami H, Bessinger K, Hellmann J, Murakami S (2005) Agingdependent and -independent modulation of associative learning behavior by insulin/insulin-like growth factor-1 signal in Caenorhabditis elegans. J Neurosci 25:10894-10904. CrossRef Medline

Nakamura H, Kojima S, Kobayashi S, Ito I, Fujito Y, Suzuki H, Ito E (1999a) Physiological characterization of lip and tentacle nerves in Lymnaea stagnalis. Neurosci Res 33:291-298. CrossRef Medline

Nakamura H, Kobayashi S, Kojima S, Urano A, Ito E (1999b) PKAdependent regulation of synaptic enhancement between a buccal motor neuron and its regulatory interneuron in Lymnaea stagnalis. Zool Sci 16:387-394. CrossRef

Nikitin ES, Vavoulis DV, Kemenes I, Marra V, Pirger Z, Michel M, Feng J, O'Shea M, Benjamin PR, Kemenes G (2008) Persistent sodium current is a nonsynaptic substrate for long-term associative memory. Curr Biol 18:1221-1226. CrossRef Medline

Oda S, Tomioka M, Iino Y (2011) Neuronal plasticity regulated by the insulin-like signaling pathway underlies salt chemotaxis learning in Caenorhabditis elegans. J Neurophysiol 106:301-308. CrossRef Medline

Ohnishi M, Matsumoto T, Nagashio R, Kageyama T, Utsuki S, Oka H, Okayasu I, Sato Y (2009) Proteomics of tumor-specific proteins in cerebrospinal fluid of patients with astrocytoma: usefulness of gelsolin protein. Pathol Int 59:797-803. CrossRef Medline

Orr MV, Hittel K, Lukowiak K (2009) "Different strokes for different folks": geographically isolated strains of Lymnaea stagnalis only respond to sympatric predators and have different memory forming capabilities. J Exp Biol 212:2237-2247. CrossRef Medline

Ramsey MM, Adams MM, Ariwodola OJ, Sonntag WE, Weiner JL (2005) Functional characterization of des-IGF-1 action at excitatory synapses in the CA1 region of rat hippocampus. J Neurophysiol 94:247-254. CrossRef Medline

Ribeiro MJ, Serfőz̋ Z, Papp A, Kemenes I, O’Shea M, Yin JC, Benjamin PR, Kemenes G (2003) Cyclic AMP response element-binding (CREB)-like proteins in a molluscan brain: cellular localization and learning-induced phosphorylation. Eur J Neurosci 18:1223-1234. CrossRef Medline

Roovers E, Vincent ME, van Kesteren E, Geraerts WP, Planta RJ, Vreugdenhil E, van Heerikhuizen H (1995) Characterization of a putative molluscan insulin-related peptide receptor. Gene 162:181-188. CrossRef Medline

Rose RM, Benjamin PR (1979) The relationship of the central motor pattern to the feeding cycle of Lymnaea stagnalis. J Exp Biol 80:137-163. Medline

Rosenegger D, Wright C, Lukowiak K (2010) A quantitative proteomic analysis of long-term memory. Mol Brain 3:9. CrossRef Medline

Sadamoto H, Yamanaka M, Hatakeyama D, Nakamura H, Kojima S, Yamashita M, Ito E (2000) Developmental study of anatomical substrate for conditioned taste aversion in Lymnaea stagnalis. Zool Sci 17:141-148. CrossRef

Sadamoto H, Sato H, Kobayashi S, Murakami J, Aonuma H, Ando H, Fujito Y, Hamano K, Awaji M, Lukowiak K, Urano A, Ito E (2004) CREB in the pond snail Lymnaea stagnalis: cloning, gene expression, and function in identifiable neurons of the central nervous system. J Neurobiol 58:455466. CrossRef Medline

Sadamoto H, Kitahashi T, Fujito Y, Ito E (2010) Learning-dependent gene expression of CREB1 isoforms in the molluscan brain. Front Behav Neurosci 4:25. Medline

Sadamoto H, Saito K, Muto H, Kinjo M, Ito E (2011) Direct observation of dimerization between different CREB1 isoforms in a living cell. PLoS One 6:e20285. CrossRef Medline

Sakakibara M (2006) Comparative study of visuo-vestibular conditioning in Lymnaea stagnalis. Biol Bull 210:298-307. CrossRef Medline

Sanna PP, Cammalleri M, Berton F, Simpson C, Lutjens R, Bloom FE, Francesconi W (2002) Phosphatidylinositol 3-kinase is required for the expression but not for the induction or the maintenance of long-term potentiation in the hippocampal CA1 region. J Neurosci 22:3359-3365. Medline

Smit AB, Vreugdenhil E, Ebberink RH, Geraerts WP, Klootwijk J, Joosse J (1988) Growth-controlling molluscan neurons produce the precur- 
sor of an insulin-related peptide. Nature 331:535-538. CrossRef Medline

Smit AB, Geraerts PM, Meester I, van Heerikhuizen H, Joosse J (1991) Characterization of a cDNA clone encoding molluscan insulin-related peptide II of Lymnaea stagnalis. Eur J Biochem 199:699-703. CrossRef Medline

Smit AB, Thijsen SF, Geraerts WP, Meester I, van Heerikhuizen H, Joosse J (1992) Characterization of a cDNA clone encoding molluscan insulinrelated peptide V of Lymnaea stagnalis. Brain Res Mol Brain Res 14:7-12. Medline

Smit AB, van Marle A, van Elk R, Bogerd J, van Heerikhuizen H, Geraerts WP (1993) Evolutionary conservation of the insulin gene structure in invertebrates: cloning of the gene encoding molluscan insulin-related peptide III from Lymnaea stagnalis. J Mol Endocrinol 11:103-113. CrossRef Medline

Smit AB, Spijker S, Van Minnen J, Burke JF, De Winter F, Van Elk R, Geraerts WP (1996) Expression and characterization of molluscan insulinrelated peptide VII from the mollusc Lymnaea stagnalis. Neuroscience 70:589-596. CrossRef Medline

Smit AB, van Kesteren RE, Li KW, Van Minnen J, Spijker S, Van Heerikhuizen H, Geraerts WP (1998) Towards understanding the role of insulin in the brain: lessons from insulin-related signaling systems in the invertebrate brain. Prog Neurobiol 54:35-54. CrossRef Medline

Smith MA, Riby LM, Eekelen JA, Foster JK (2011) Glucose enhancement of human memory: a comprehensive research review of the glucose memory facilitation effect. Neurosci Biobehav Rev 35:770-783. CrossRef Medline

Soos MA, Siddle K, Baron MD, Heward JM, Luzio JP, Bellatin J, Lennox ES (1986) Monoclonal antibodies reacting with multiple epitopes on the human insulin receptor. Biochem J 235:199-208. Medline

Straub VA, Staras K, Kemenes G, Benjamin PR (2002) Endogenous and network properties of Lymnaea feeding central pattern generator interneurons. J Neurophysiol 88:1569-1583. Medline

Straub VA, Kemenes I, O'Shea M, Benjamin PR (2006) Associative memory stored by functional novel pathway rather than modifications of preexisting neuronal pathways. J Neurosci 26:4139-4146. CrossRef Medline

Straub VA, Grant J, O'Shea M, Benjamin PR (2007) Modulation of serotonergic neurotransmission by nitric oxide. J Neurophysiol 97:1088-1099. Medline

Sugai R, Shiga H, Azami S, Watanabe T, Sadamoto H, Fujito Y, Lukowiak K,
Ito $\mathrm{E}$ (2006) Taste discrimination in conditioned taste aversion of the pond snail Lymnaea stagnalis. J Exp Biol 209:826-833. CrossRef Medline

Sugai R, Azami S, Shiga H, Watanabe T, Sadamoto H, Kobayashi S, Hatakeyama D, Fujito Y, Lukowiak K, Ito E (2007) One-trial conditioned taste aversion in Lymnaea: good and poor performers in long-term memory acquisition. J Exp Biol 210:1225-1237. CrossRef Medline

Taylor R, Soos MA, Wells A, Argyraki M, Siddle K (1987) Insulin-like and insulin-inhibitory effects of monoclonal antibodies for different epitopes on the human insulin receptor. Biochem J 242:123-129. Medline

Tomioka M, Adachi T, Suzuki H, Kunitomo H, Schafer WR, Iino Y (2006) The insulin/PI 3-kinase pathway regulates salt chemotaxis learning in Caenorhabditis elegans. Neuron 51:613-625. CrossRef Medline

Trannoy S, Redt-Clouet C, Dura JM, Preat T (2011) Parallel processing of appetitive short- and long-term memories in Drosophila. Curr Biol 21: 1647-1653. CrossRef Medline

Wagatsuma A, Sadamoto H, Kitahashi T, Lukowiak K, Urano A, Ito E (2005) Determination of the exact copy numbers of particular mRNAs in a single cell by quantitative real-time RT-PCR. J Exp Biol 208:2389-2398. CrossRef Medline

Wagatsuma A, Azami S, Sakura M, Hatakeyama D, Aonuma H, Ito E (2006) De Novo synthesis of CREB in a presynaptic neuron is required for synaptic enhancement involved in memory consolidation. J Neurosci Res 84:954-960. CrossRef Medline

Wan Q, Xiong ZG, Man HY, Ackerley CA, Braunton J, Lu WY, Becker LE, MacDonald JF, Wang YT (1997) Recruitment of functional GABA receptors to postsynaptic domains by insulin. Nature 388:686-690. CrossRef Medline

Wu SP, Lu KT, Chang WC, Gean PW (1999) Involvement of mitogenactivated protein kinase in hippocampal long-term potentiation. J Biomed Sci 6:409-417. CrossRef Medline

Yeoman MS, Patel BA, Arundell M, Parker K, O'Hare D (2008) Synapsespecific changes in serotonin signalling contribute to age-related changes in the feeding behaviour of the pond snail, Lymnaea. J Neurochem 106: 1699-1709. CrossRef Medline

Zhao W, Chen H, Xu H, Moore E, Meiri N, Quon MJ, Alkon DL (1999) Brain insulin receptors and spatial memory. Correlated changes in gene expression, tyrosine phosphorylation, and signaling molecules in the hippocampus of water maze trained rats. J Biol Chem 274:34893-34902. CrossRef Medline 